\title{
Procedural Documentation and Accuracy Assessment of Bathymetric Maps and Area/Capacity Tables for Small Reservoirs
}

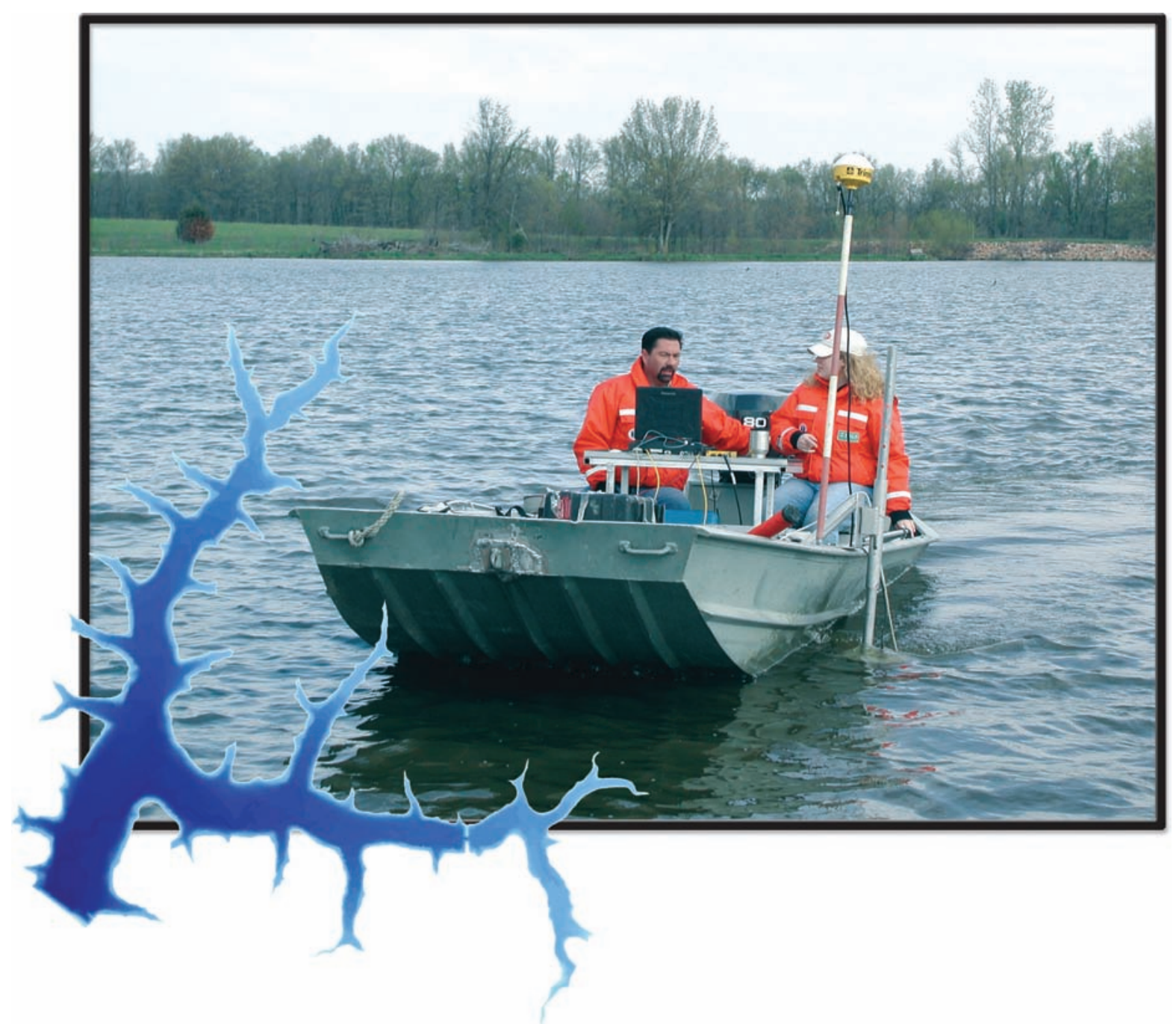

Scientific Investigations Report 2006-5208 
Cover photograph: Hydrologic technicians collecting bathymetric data on a small reservoir, 2001. 


\section{Procedural Documentation and Accuracy Assessment of Bathymetric Maps and Area/Capacity Tables for Small Reservoirs}

By Gary L. Wilson and Joseph M. Richards

Scientific Investigations Report 2006-5208 


\title{
U.S. Department of the Interior DIRK KEMPTHORNE, Secretary
}

\author{
U.S. Geological Survey \\ P. Patrick Leahy, Acting Director
}

\section{U.S. Geological Survey, Reston, Virginia: 2006}

For sale by U.S. Geological Survey, Information Services

Box 25286, Denver Federal Center

Denver, CO 80225

For more information about the USGS and its products:

Telephone: 1-888-ASK-USGS

World Wide Web: http://www.usgs.gov/

Any use of trade, product, or firm names in this publication is for descriptive purposes only and does not imply endorsement by the U.S. Government.

Although this report is in the public domain, permission must be secured from the individual copyright owners to reproduce any copyrighted materials contained within this report.

Suggested citation:

Wilson, G.L., and Richards, J.M., 2006, Procedural Documentation and Accuracy Assessment of Bathymetric Maps and Area/Capacity Tables for Small Reservoirs: U.S. Geological Survey Scientific Investigations Report 2006-5208, 24 p. plus oversize figs. 


\section{Contents}

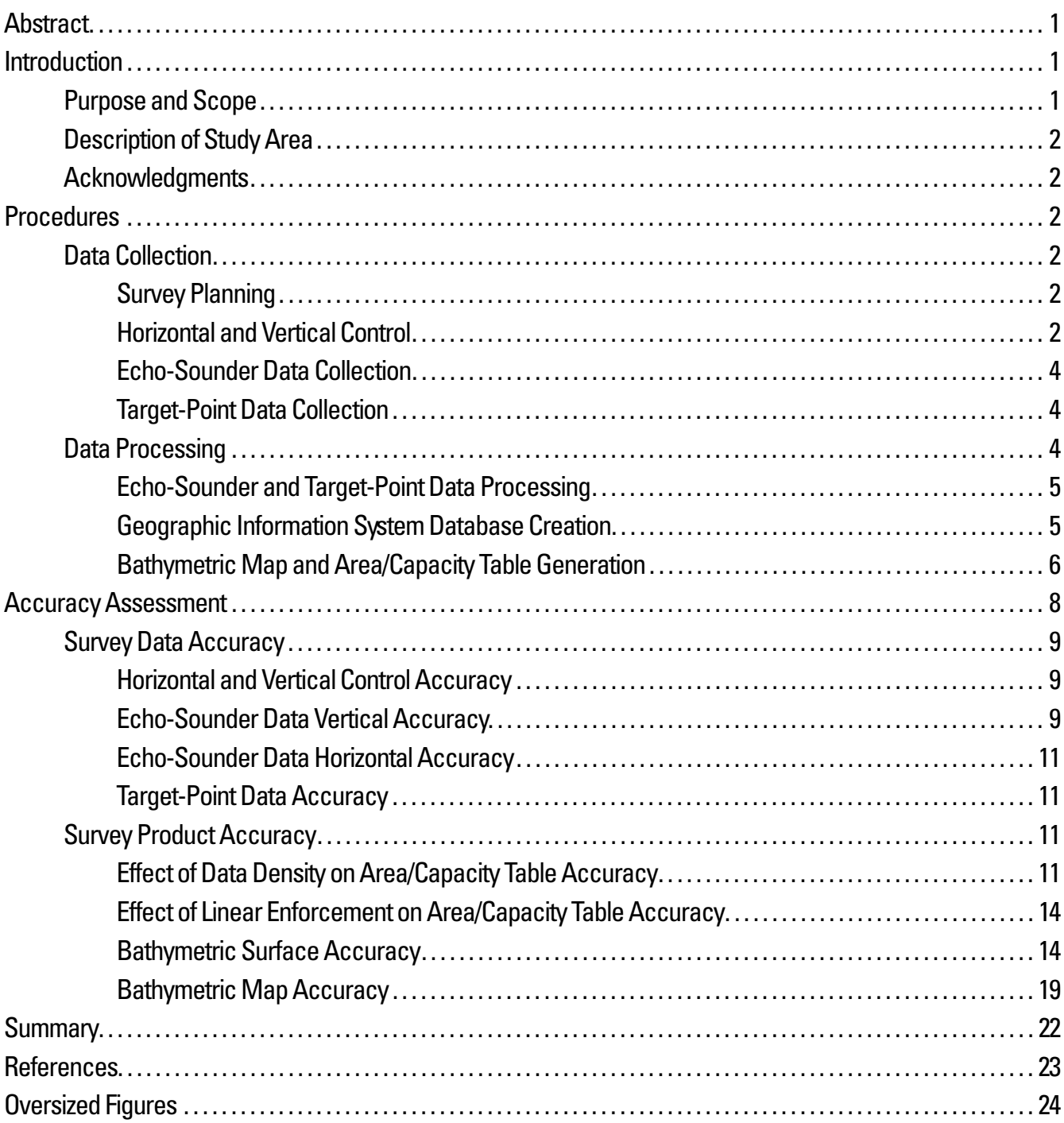

\section{Figures}

1. Map showing location of Sugar Creek Lake near Moberly, Missouri.........................

2. Map showing planned 50-foot interval survey and 490-foot interval quality-assurance transects

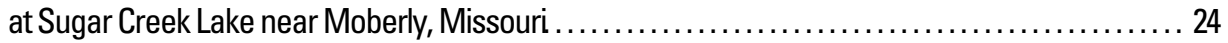

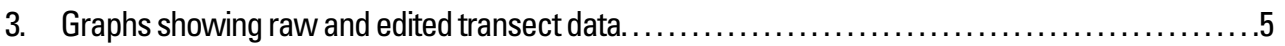

4. Figure showing representation of changes in bathymetric contours for a stream channel with linear-enforcement data added.............................................. 6

5. Figure showing representation of initial surface contours and cartographically smoothed

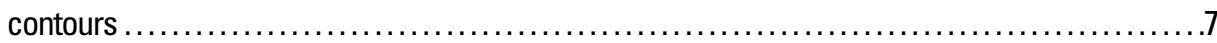

6. Figure showing representation of survey data and bathymetric contours showing comparison

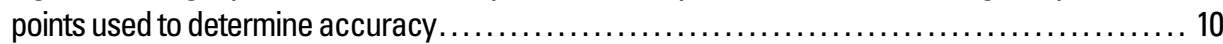


7-11. Maps showing-

7. Echo-sounder, target-point, and land-survey data collected at Sugar Creek Lake near Moberly, Missouri, with shoreline digitized from aerial photography, used to create the bathymetric surface model using a transect interval of approximately 50 feet ....24

8. Echo-sounder, target-point, and land-survey data collected at Sugar Creek Lake near Moberly, Missouri, with shoreline digitized from aerial photography, used to create the bathymetric surface model using a transect interval of approximately 100 feet and linear-enforcement data .....

9. Echo-sounder, target-point, and land-survey data collected at Sugar Creek Lake near Moberly, Missouri, with shoreline digitized from aerial photography, used to create the bathymetric surface model using a transect interval of approximately 200 feet and linear-enforcement data.

10. Echo-sounder, target-point, and land-survey data collected at Sugar Creek Lake near Moberly, Missouri, with shoreline digitized from aerial photography, used to create the bathymetric surface model using a transect interval of approximately 400 feet and linear-enforcement data.

11. Echo-sounder, target-point, and land-survey data collected at Sugar Creek Lake near Moberly, Missouri, with shoreline digitized from aerial photography, used to create the bathymetric surface model using a transect interval of approximately 800 feet and linear-enforcement data.

12-15. Graphs showing-

12. Elevation-area and elevation-capacity curves for bathymetric surfaces using different transect intervals

13. Relative percent difference of elevation-area and elevation-capacity curves from bathymetric surfaces created using different transect intervals as compared to the bathymetric surface created from 50 -foot transect intervals.

14. Elevation-area and elevation-capacity curves for bathymetric surfaces using different transect intervals and linear-enforcement data

15. Relative percent difference of elevation-area and elevation-capacity curves from bathymetric surfaces created using different transect intervals and linear-enforcement data as compared to the bathymetric surface created from 50 -foot transect intervals...... 18

16-20. Maps showing-

16. Bathymetric contours of Sugar Creek Lake near Moberly, Missouri, created from a transect interval of approximately 50 feet

17. Bathymetric contours of Sugar Creek Lake near Moberly, Missouri, created from a transect interval of approximately 100 feet and linear-enforcement data.

18. Bathymetric contours of Sugar Creek Lake near Moberly, Missouri, created from a transect interval of approximately 200 feet and linear-enforcement data.

19. Bathymetric contours of Sugar Creek Lake near Moberly, Missouri, created from a transect interval of approximately 400 feet and linear-enforcement data.

20. Bathymetric contour map of Sugar Creek Lake near Moberly, Missouri, created from a transect interval of approximately 800 feet and linear-enforcement data. 


\section{Tables}

1. Comparison of National Map Accuracy Standard (NMAS) and National Standard for Spatial

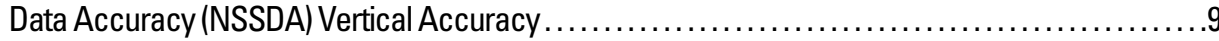

2. Area/capacity tables from bathymetric surface created using different transect intervals....... 12

3. Area/capacity tables from bathymetric surface created using different transect intervals

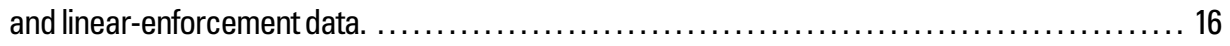

4. Vertical accuracies (at the 95 percent confidence level) of bathymetric surfaces created using different transect intervals without and with linear-enforcement data. ............... 19

5. Vertical accuracies (at the 95 percent confidence level) of bathymetric surfaces created using different 100-foot transect intervals without and with linear-enforcement data, and

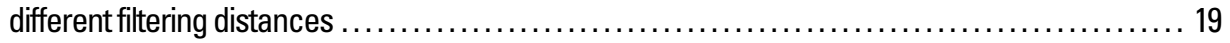

6. Contour lengths from bathymetric surface models created using different transect intervals and linear-enforcement data with difference from the control data set (50-foot transect interval)

7. Bathymetric surface and contour accuracies of previously surveyed lakes with similar size and geometry processed using documented procedures.. 


\section{Conversion Factors and Datum}

\begin{tabular}{|c|c|c|}
\hline Multiply & By & To obtain \\
\hline \multicolumn{3}{|c|}{ Length } \\
\hline inch (in.) & 2.54 & centimeter $(\mathrm{cm})$ \\
\hline inch (in.) & 25.4 & millimeter (mm) \\
\hline foot $(\mathrm{ft})$ & 0.3048 & meter $(\mathrm{m})$ \\
\hline mile (mi) & 1.609 & kilometer (km) \\
\hline \multicolumn{3}{|c|}{ Area } \\
\hline acre & 4,047 & square meter $\left(\mathrm{m}^{2}\right)$ \\
\hline acre & 0.004047 & square kilometer $\left(\mathrm{km}^{2}\right)$ \\
\hline \multicolumn{3}{|c|}{ Volume } \\
\hline acre-foot (acre-ft) & 1,233 & cubic meter $\left(\mathrm{m}^{3}\right)$ \\
\hline \multicolumn{3}{|c|}{ Flow rate } \\
\hline mile per hour (mi/h) & 1.609 & kilometer per hour $(\mathrm{km} / \mathrm{h})$ \\
\hline
\end{tabular}

Temperature in degrees Celsius $\left({ }^{\circ} \mathrm{C}\right)$ may be converted to degrees Fahrenheit $\left({ }^{\circ} \mathrm{F}\right)$ as follows:

${ }^{\circ} \mathrm{F}=\left(1.8 \mathrm{x}^{\circ} \mathrm{C}\right)+32$

Temperature in degrees Fahrenheit $\left({ }^{\circ} \mathrm{F}\right)$ may be converted to degrees Celsius $\left({ }^{\circ} \mathrm{C}\right)$ as follows:

${ }^{\circ} \mathrm{C}=\left({ }^{\circ} \mathrm{F}-32\right) / 1.8$

Vertical coordinate information is referenced to the North American Vertical Datum of 1988 (NAVD 88).

Horizontal coordinate information is referenced to the North American Datum of 1983 (NAD 83).

Elevation, as used in this report, refers to distance above the vertical datum. 


\title{
Procedural Documentation and Accuracy Assessment of Bathymetric Maps and Area/Capacity Tables for Small Reservoirs
}

\author{
By Gary L. Wilson and Joseph M. Richards
}

\section{Abstract}

Because of the increasing use and importance of lakes for water supply to communities, a repeatable and reliable procedure to determine lake bathymetry and capacity is needed. A method to determine the accuracy of the procedure will help ensure proper collection and use of the data and resulting products. It is important to clearly define the intended products and desired accuracy before conducting the bathymetric survey to ensure proper data collection.

A survey-grade echo sounder and differential global positioning system receivers were used to collect water-depth and position data in December 2003 at Sugar Creek Lake near Moberly, Missouri. Data were collected along planned transects, with an additional set of quality-assurance data collected for use in accuracy computations. All collected data were imported into a geographic information system database. A bathymetric surface model, contour map, and area/capacity tables were created from the geographic information system database.

An accuracy assessment was completed on the collected data, bathymetric surface model, area/capacity table, and contour map products. Using established vertical accuracy standards, the accuracy of the collected data, bathymetric surface model, and contour map product was 0.67 foot, 0.91 foot, and 1.51 feet at the 95 percent confidence level. By comparing results from different transect intervals with the quality-assurance transect data, it was determined that a transect interval of 1 percent of the longitudinal length of Sugar Creek Lake produced nearly as good results as 0.5 percent transect interval for the bathymetric surface model, area/capacity table, and contour map products.

\section{Introduction}

Advances in computer and echo-sounder technology have made it possible to conduct accurate and repeatable bathymetric surveys. Those surveys can be used to compute area/capacity tables for lakes that managers can use to more reliably regulate the use of these valuable resources. Managers of water-supply lakes need an accurate estimate of the lake volume to ensure that a sufficient amount of water is available for such purposes as providing consistent recreation pool levels, preserving downstream aquatic habitat, flood abatement, water supply, and power generation. Reservoir volume is particularly important for managers of water-supply lakes or reservoirs during periods of drought, unexpected population growth, or exceptionally high water use in the area supplied by the lake.

As a lake ages, sedimentation will cause a loss of storage capacity; as a result, the area/capacity table for the lake (if one exists) will over estimate the capacity of the lake. Previous methods of computing sediment accumulation rates and the associated storage capacity loss were based on either a small number of stationary transect locations surveyed periodically, or a coarse grid-based sediment sampling system. The transect profiles were compared to determine the capacity changes caused by sedimentation. The area/capacity table was then adjusted based on extrapolating the transect data to the other parts of the lake, and recomputing the area/capacity table.

Documentation is needed for equipment and procedures used in accurate and repeatable bathymetric surveys made at recurring intervals to evaluate the change in capacity or the change in aquatic habitat associated with sediment accumulation or scour in the lake. The bathymetric changes can be documented, and rates of accumulation calculated so that managers can better regulate the water-supply resource.

\section{Purpose and Scope}

The purpose of this report is to document the methodology for collecting depth data using a survey-grade boat-mounted echo sounder, and for creating bathymetric maps and area/ capacity tables from the data. The report also provides an accuracy assessment of the equipment used during the survey, the data collected, and the procedures used to compile the surveyed data. This documentation can be used as a guide for future bathymetric surveys. 


\section{Procedural Documentation and Accuracy Assessment of Bathymetric Maps and Area/Capacity Tables for Small Reservoirs}

\section{Description of Study Area}

Data for this study were collected at Sugar Creek Lake near Moberly, Missouri (fig. 1). The lake has a full-pool surface area of approximately 330 acres and is located approximately 4 mi (miles) northwest of Moberly, Missouri, in Randolph County. The lake primarily is used for recreation and drinkingwater supply for the town of Moberly, Missouri. An earthen dam approximately 38 -ft (feet) high and 1,125-ft long was constructed across the Sugar Creek valley in 1922 (City of Moberly, written commun., 2003). The elevation of the top of the dam is approximately $754 \mathrm{ft}$, with a $90-\mathrm{ft}$ wide concrete spillway located near the right bank (west end) at an elevation of $746.8 \mathrm{ft}$. During the study, the lake level was $0.1 \mathrm{ft}$ above the spillway elevation.

The study area is located in the dissected till plains physiographic province (Fenneman, 1938). The landscape is characterized by gently rolling hills of primarily rural agricultural land, consisting of pasture and cropland intermixed with forested areas. The lithology of the area is characterized by generally flat-lying Pennsylvanian-age sandstone and shale bedrock overlain by glacial loess deposits. The bedrock crops out along the steep slopes of the lake above the water surface. The mean annual precipitation for the area is approximately $40 \mathrm{in}$. (inches; National Oceanic and Atmospheric Administration, 2003) and the mean annual runoff is approximately $10.7 \mathrm{in}$. (Hauck and Nagel, 2004).

\section{Acknowledgments}

The authors thank Matt Everts, Sugar Creek Lake manager, for his assistance during the bathymetric surveying.

\section{Procedures}

Using global positioning system (GPS) equipment, survey-grade echo sounder, and geographic information system (GIS) software, a bathymetric survey was completed and formed the basis for determination of area/capacity and generation of a bathymetric map of Sugar Creek Lake. Consistency in data-collection and processing procedures is important in producing accurate and reliable results. Data-collection and processing procedures used to produce an area/capacity table and bathymetric map are described in the following sections.

\section{Data Collection}

Data collection consists of several different operations, which includes survey planning, establishing horizontal and vertical control, and collecting land-surface elevation. Procedures used to collect data for the generation of an area/capacity table and bathymetric map are described in the following sections.

\section{Survey Planning}

Survey planning begins by determining the accuracy requirements and the products to be produced, and then choosing the appropriate interval for survey transects that are oriented perpendicular to the long axis of the lake (fig. 2). Data, such as the lake shoreline, topographic maps, and aerial photography, were compiled for use in the GIS, which was used to build the base maps used by survey crews. Digital GIS files simplify the planning process and allow for more accurate time and personnel estimates for the survey. Depending on the desired products and accuracy, transect spacing is computed to be a certain percentage of the longitudinal length of the lake. A minimum transect interval of $30 \mathrm{ft}$ is feasible because of the practicality of maintaining boat position along the planned transect during the survey. For Sugar Creek Lake, the transect spacing was computed by dividing the longitudinal distance of the lake by 200 , resulting in a transect interval of $50 \mathrm{ft}$. This high-density data set allowed for a detailed baseline area/capacity table and bathymetric map to be defined, which was used to evaluate results using different transect intervals. Transects were used to ensure consistent data collection and to allow the survey crew to keep track of their progress. For quality assurance, a second set of transects for an independent data set were defined so survey accuracy could be assessed. These transects were oriented at an oblique angle (30 to 45 degrees) to the original planned transects and were spaced to intersect the original transects in varying locations so that a statistical analysis of accuracy could be obtained. For this survey, a spacing of five times the original transect spacing produced enough intersection points for a statistical analysis. By summing the lengths of the planned transects, a total estimate of transect distance can be determined. An estimate of the time to survey the lake can then be calculated by dividing the total transect distance by the assumed average boat speed and adding time to move between transects. The survey transects and lake boundary were used in the datacollection software to organize and monitor the data-collection process.

\section{Horizontal and Vertical Control}

Horizontal and vertical control points were established using a survey-grade differentially-corrected GPS and real-time kinematic (RTK) surveying techniques (hereafter referred to as RTK GPS). The RTK GPS positioning uses at least two GPS receivers: a reference (base) receiver and one or more rover receivers. Horizontal and vertical position accuracy for the data collected with the survey-grade GPS equipment were verified by recording differentially-corrected GPS positions with the reference (base) receiver set up on a known geodetic control point (KD0053). Two additional known control points (KD0019 and BM201) were surveyed to ensure stability of all control points used (fig. 1). Marks were set at the lake to establish a reference datum and allow the determination of water-surface elevation at the time of the survey. After survey control 


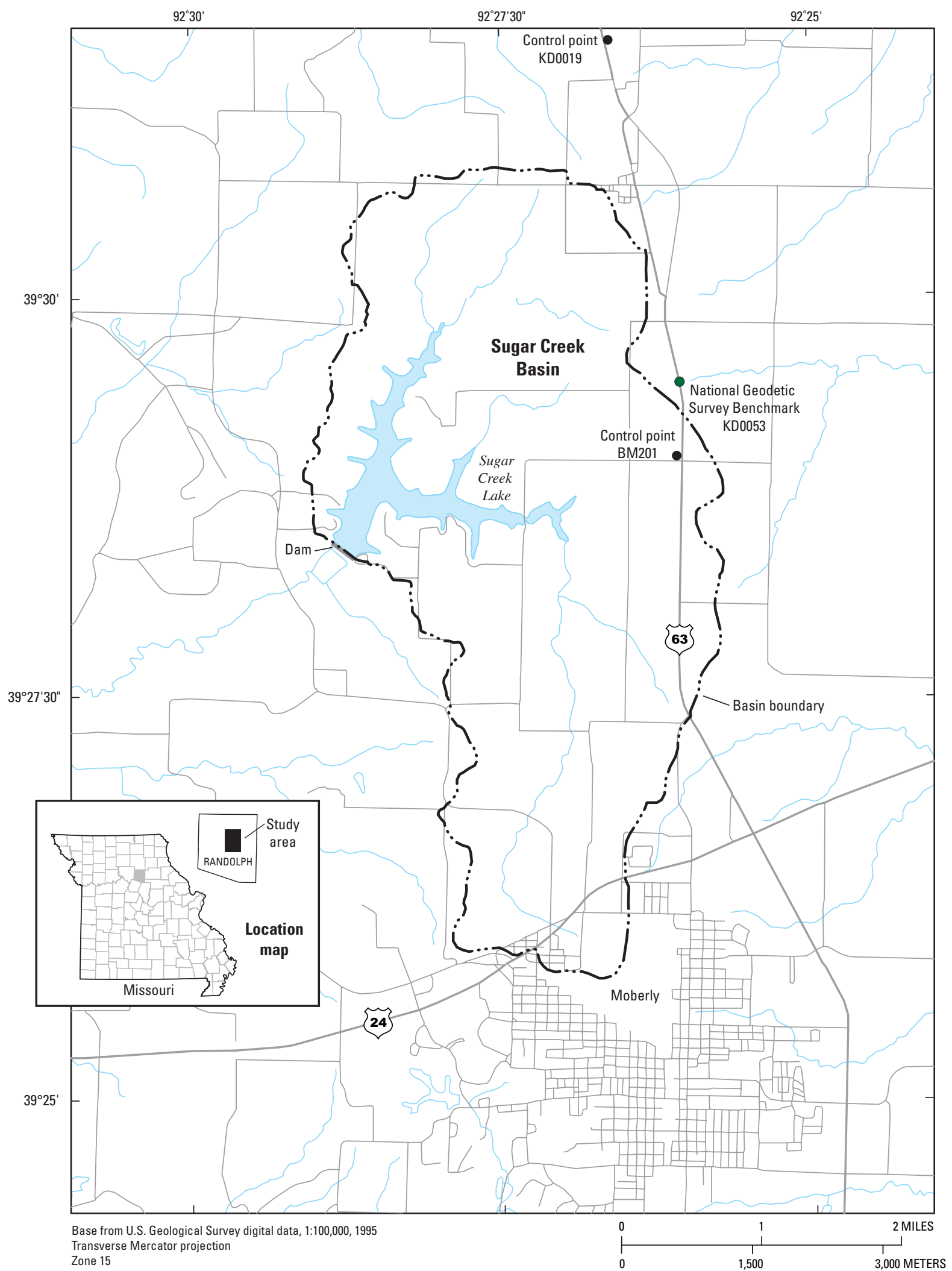

Figure 1. Location of Sugar Creek Lake near Moberly, Missouri. 


\section{Procedural Documentation and Accuracy Assessment of Bathymetric Maps and Area/Capacity Tables for Small Reservoirs}

was established, land-surface elevation data were collected to enhance existing elevation data for features such as the dam, spillway, boat ramps, and other areas that seemed to be different from previously published contour maps. Land-surface data were collected on foot, or by attaching the rover receiver to a vehicle and driving over the accessible areas.

\section{Echo-Sounder Data Collection}

A survey-grade echo sounder with a $200 \mathrm{kHz}$ (kilohertz) transducer was used to measure water depths. An echo sounder measures water depth by measuring the time interval required for ultrasonic waves to travel, at a known velocity, from a known point (vessel) to a reflecting surface (lake bottom) and then return. A minimum depth limitation exists when the reflecting surface is too close to the echo-sounder face, which for this survey was approximately $2.6 \mathrm{ft}$. For accurate surveying, sound velocity must be determined and entered into the echo sounder. Sound velocity in water is dependent upon the salinity, temperature, and depth. For freshwater lakes, salinity and the shallow depths typically encountered are not major factors affecting sound speed (U.S. Army Corps of Engineers, 2002).

Before surveying, the echo sounder was calibrated to ensure accurate depth soundings (often referred to as a bar check). Water temperature was measured to determine an initial sound velocity for the calibration process. A plate was then placed at a known depth below the transducer face (usually $5 \mathrm{ft}$ ), and the echo sounder was calibrated to record this depth. The plate was then lowered deeper (approximately the deepest point of the lake) and the speed of sound value was adjusted until the depth recorded by the echo sounder matched the depth of the calibrated plate $(+/-0.1 \mathrm{ft})$. The plate was returned to the first shallower depth to recheck the value recorded by the echo sounder. Multi-depth calibration of the echo sounder was performed twice each day to ensure a reliable depth measurement (U.S. Army Corps of Engineers, 2002).

Horizontal coordinates of the depth values collected from the echo sounder were collected using a differential GPS receiver (DGPS), but not using RTK techniques. The DGPS antenna was mounted directly above the echo sounder. The DGPS receiver uses a differential correction signal transmitted from permanent reference bases distributed across the country. The horizontal spacing of the depth data was dependent on the ping rate of the echo sounder and the speed of the boat. The ping rate was 5 pings per second and the boat speed was kept between 3 to $5 \mathrm{mi} / \mathrm{h}$ (miles per hour), resulting in a horizontal spacing of the depth data to be approximately 0.9 to $1.5 \mathrm{ft}$. In addition to digitally recording the data, the signals representing the depth values were recorded in hard copy form on a paper chart (U.S. Army Corps of Engineers, 2002).

To determine if the horizontal coordinates were collected and stored for the correct depth value, the DGPS latency was computed. Latency is the time difference or lag between the time positioning data are received and the time the computed/ processed position reaches the data logging module and is time tagged. Latency typically results in a negative along-track spatial displacement of the depth value. While surveying at slow speeds, this displacement will be small (U.S. Army Corps of Engineers, 2002). The latency was computed by measuring the along-track displacement of soundings from coincident lines run in opposite directions over a steep slope. The latency delay for our equipment was 0.3 seconds. The boat speed during our survey made the displacement small enough to be considered within the horizontal accuracy of our DGPS system and a correction was not applied. However, a latency test needs to be performed before each survey and the latency correction should be applied.

Coordinates and depth values were collected along predetermined transects established during the survey setup. Computer software was used to manage the sequential collection of transect data and to monitor data collection along the transect path. Additional data were collected where features such as bluffs, creek channels, depressions, and submerged ridges/ mounds were present in the echo-sounder data, or where present on topographic maps. Though none were collected for this study, additional data around the dam can help to properly define the upstream face of the dam structure.

\section{Target-Point Data Collection}

Target points are additional depth data collected that were not a part of the planned transects for the lake. They were collected to define the water depth where transect data were sparse, such as coves, shallow areas, and areas where the bottom elevation changes rapidly. Target points were also collected between the transects to further define the lake bottom.

Target-point data were collected using the echo sounder for depths greater than about $2.6 \mathrm{ft}$ (minimum measurable depth) and were collected using a wading rod for shallower depths. The wading rod was 4-ft long and is marked off in tenths of feet. The wading rod was placed in the water with the rod firmly resting on the bottom near the location of the DGPS antenna, and a depth measurement was read from the rod. Coordinates of the target points were collected using the DGPS, and the data were entered into the computer. Collection of echosounder data along the transects was stopped before reaching the shoreline because of the minimum depth limitation of the echo sounder, thus precluding the collection of shoreline points with each transect. Target points defining the shoreline were collected using a boat with the DGPS antenna mounted on the front of the boat. Coordinates were recorded and assigned a depth value of zero. The density of shoreline target points collected around the lake varied, but was generally greater where the shoreline changed shape rapidly.

\section{Data Processing}

Echo-sounder and target-point data were processed using hydrographic software. All data were compiled into an ArcGIS 
package (Environmental Systems Research Institute, 2005). ArcGIS is a collection of software packages that allow data editing and attribution, data display and review of data, data processing, generation of interpolated data, and map-product creation. Horizontal and vertical control, land-survey data, echo-sounder depth data, target points, field notes and sketches, photographs, aerial photography, and topographic map data were used to generate, validate, and edit the bathymetric surface.

\section{Echo-Sounder and Target-Point Data Processing}

The lake water-surface elevation was computed from the reference marks that were established using the horizontal and vertical control points by measuring from reference marks to water surface. Using hydrographic software, echo-sounder and target-point depth data were converted to bottom elevations by subtracting the depth from the lake water-surface elevation during the survey period. Raw transect data were reviewed by plotting bottom elevation in relation to transect length (fig. 3). Fish, trees, limbs, and other submerged objects can cause false reflections in the transect data. When the water depth was less than the minimum measurable distance, erroneous constant depths were recorded. These data were removed and the resulting transect data were saved as an edited transect (fig. 3).

\section{Geographic Information System Database Creation}

The edited transects were incorporated into the GIS database. In addition, the target points and land-survey data were verified for accuracy and incorporated into the GIS database. Field notes, sketches, and photographs were used to help interpret the elevation data. From aerial photographs, the shoreline of the lake was digitized using shoreline target-point data as a reference. If possible, the lake shoreline was assigned an elevation based on comparison with the elevations of the water surface, land-survey data, and transects. Topographic elevation data from the 1:24,000 scale U.S. Geological Survey (USGS) quadrangle maps were digitized to help define the land surface above the water surface at the time of the survey. If available, elevation data from light detection and ranging (LIDAR) or other photogrammetric methods could be used. All data were projected into a common horizontal datum (North American Datum of 1983, NAD83) and vertical datum (North American

\section{Raw data transect}

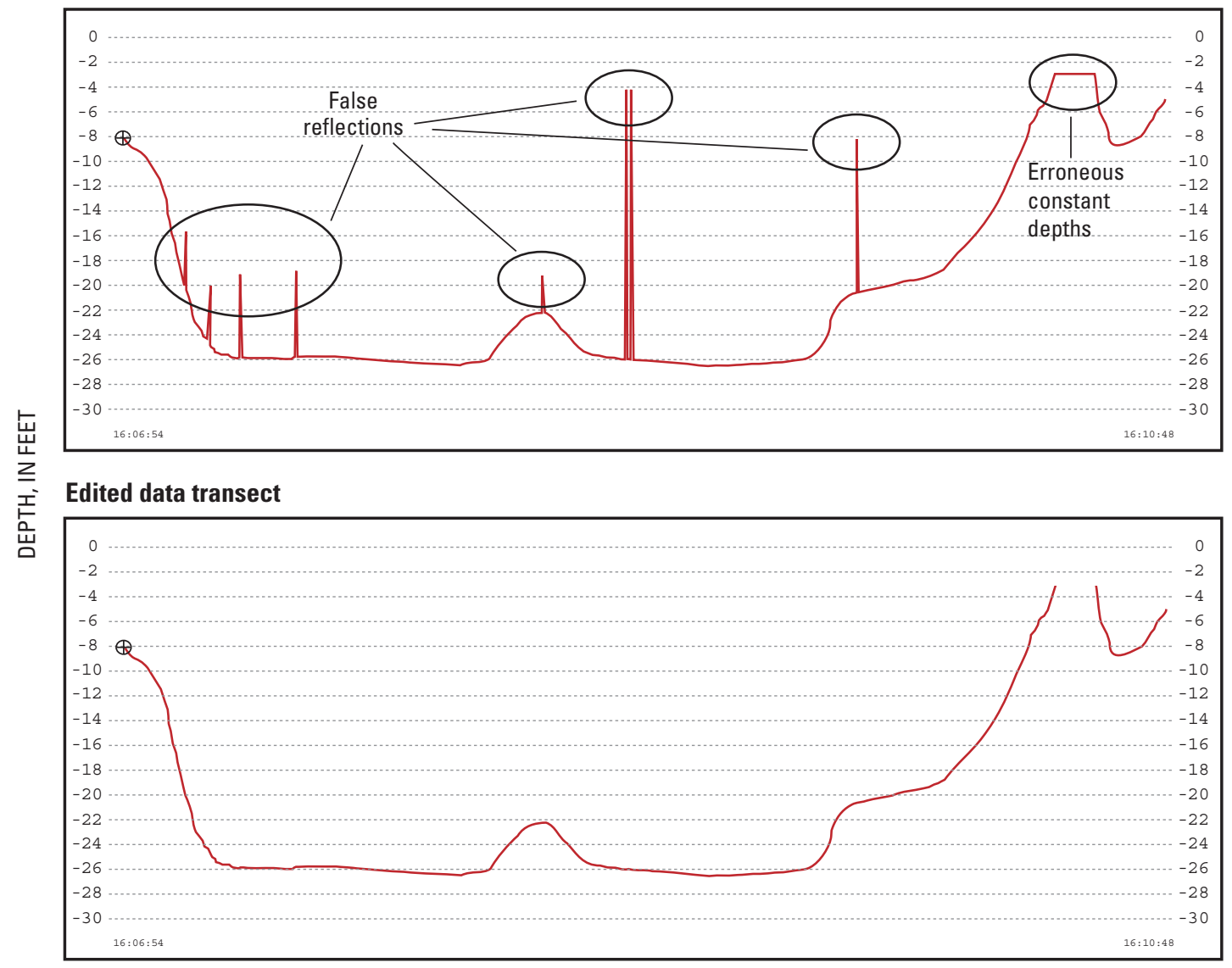

Figure 3. Raw and edited transect data. 


\section{Procedural Documentation and Accuracy Assessment of Bathymetric Maps and Area/Capacity Tables for Small Reservoirs}

Vertical Datum, NAVD88) before compilation into the GIS database.

\section{Bathymetric Map and Area/Capacity Table Generation}

A triangulated irregular network model (TIN) was generated from the data stored in the GIS database. A TIN is a collection of triangles generated using the data points as the corners. This triangular mosaic forms a continuous faceted surface, much like a jewel. The triangles are created using the Delauney criterion (Environmental Systems Research Institute, 19822005), so that all points are connected using their two nearest neighbors to form triangles. The majority of the surface model is made of long skinny triangles between transects. Though sur- faces created from triangles of this type are not ideal, the manner in which the data are collected forces the creation of these triangles. Contours were generated from the surface model.

The contours were inspected for linear features such as narrow valleys, stream channels, steep slopes, and ridges (fig. 4). The surface model (and thus the contours) often do not accurately reflect these features because the interval between transects can be large enough that the feature is not interpolated properly between transects. Linearity of narrow valleys, stream channels, steep slopes, and ridges were forced to be accurately represented in the bathymetric surface (fig. 4) by adding breakline data to the GIS database. The process of adding these data is termed "linear enforcement". For narrow valleys, stream channels, and ridges, a line was added connecting the features

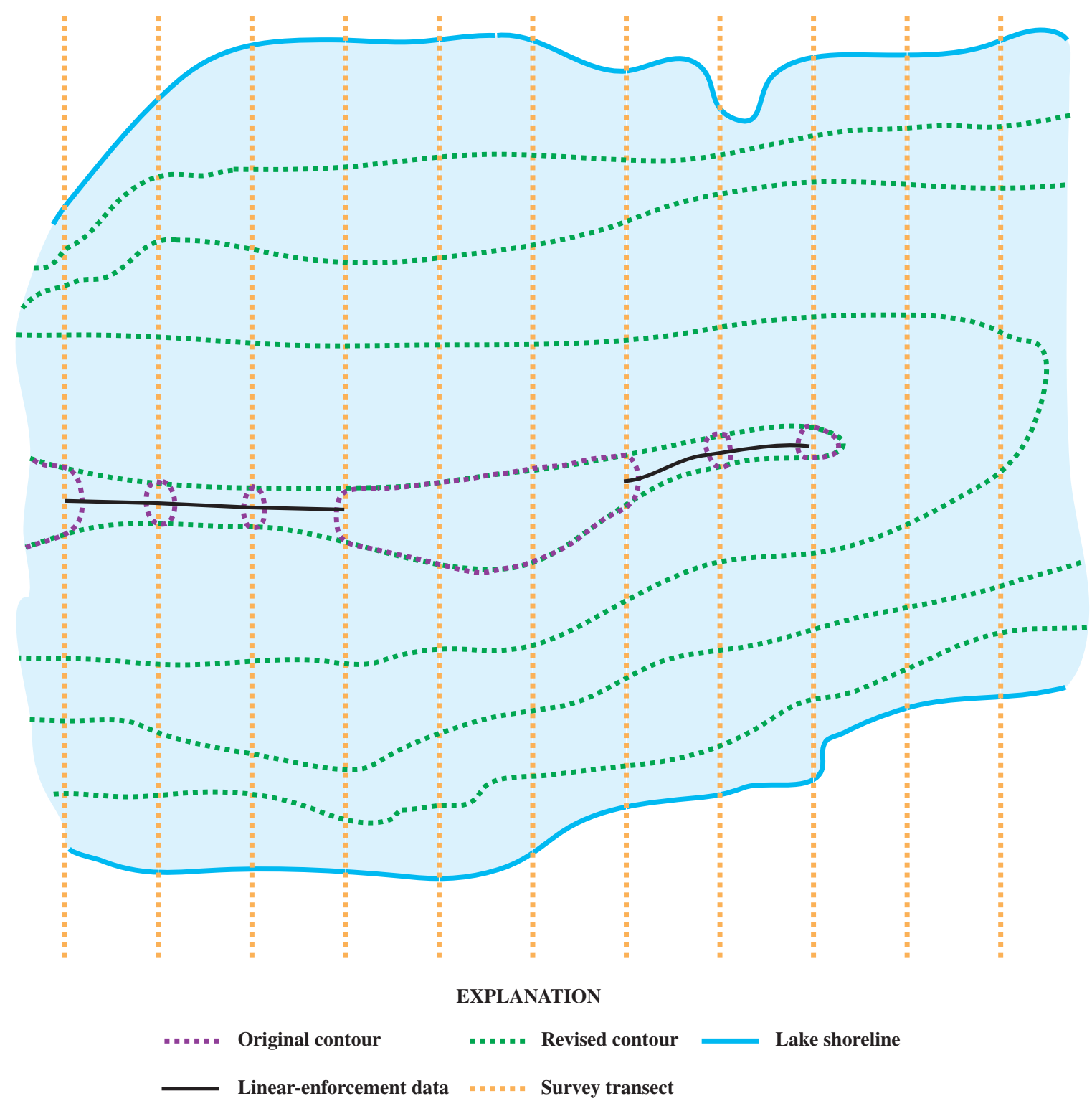

Figure 4. Representation of changes in bathymetric contours for a stream channel with linear-enforcement data added. 
between the transects. The ends of the line were attributed with the elevations of the transect data. Where needed, subsequent breaklines were added between transects. The lines were then converted to a set of points with elevations interpolated between the end points. These points are then added back to the original data set, which forces subsequent generated surfaces to more accurately represent the linear features. The same process was used for steep slopes with the line being added between transects near the bottom of the slope. These data force the surface model to represent the non-uniform change in slope. This is an iterative process that is dependent on the lake size, data density, and type of topographic features in the lake.

Contours generated from the final bathymetric surface model were edited cartographically for map production. Computer generated contours from the bathymetric surface model can appear jagged because of the numerical interpretation of the data (fig. 5). Though not numerically incorrect, this interpretation of the data does not match the cartographic interpretation of data. Therefore, the contours were edited cartographically (smoothed) to be more aesthetically pleasing on the final ver- sion of the bathymetric map. The contour lines were smoothed using an automated process that removes vertices within a specified tolerance (about 1/5 the transect interval) of each other along the contour lines. This is known as "splining" (Environmental Systems Research Institute, 1982-2005). The contour lines were then further edited graphically by removing vertices or reshaping contours using the original elevation data as a guide. Both methods required a visual inspection of the results to ensure that the contours matched the data points. The amount of splining and manual editing are dependent on the density of data collected, relative change in elevation in certain areas of the lake, and interpretive preference. Caution should be used with the automated editing process to ensure that too much of the original contour shape is not lost, which could cause some contours to cross each other in areas where the elevation changes rapidly. Area and capacity at specified water-surface elevations were calculated from the bathymetric surface model, and not from the smoothed bathymetric contour maps.

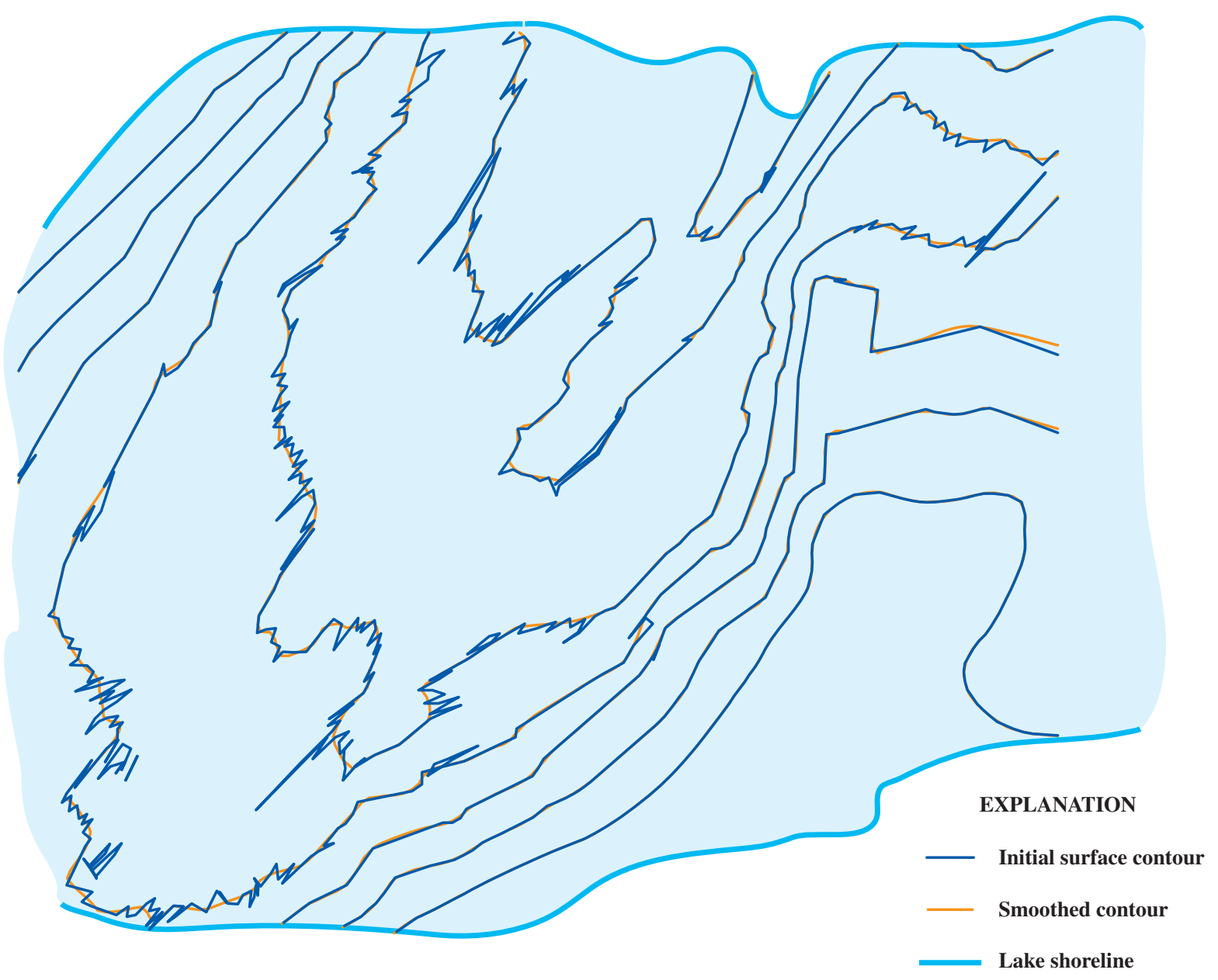

Figure 5. Representation of initial surface contours and cartographically smoothed contours. 


\section{Procedural Documentation and Accuracy Assessment of Bathymetric Maps and Area/Capacity Tables for Small Reservoirs}

\section{Accuracy Assessment}

Accuracy requirements for bathymetric data collection depend on the intended use of the data. Producing a surface model of 2-ft vertical accuracy from which an area/capacity table is computed, requires a different data-collection accuracy requirement than producing a bathymetric map of 2 -ft vertical accuracy as the following discussion will clarify. The intended use of the data must be well defined before data collection so that the data can be collected with sufficient density and quality to meet the accuracy requirements for the intended use. The quality of the data or products is specified in a statement of accuracy that defines the expected degree of uncertainty when using the product. For example, the statement "this bathymetric map tested to have $0.67-\mathrm{ft}$ fundamental vertical accuracy at the 95 percent confidence interval" means that 95 percent of all points tested on the map were within +/- $0.67 \mathrm{ft}$ of the "true" elevation. Based on these statistics, it is assumed that given any randomly selected test data set, 95 percent of those points would be within $+/-0.67 \mathrm{ft}$ of the "true" elevation; therefore, the vertical accuracy of the map product would be $+/-0.67 \mathrm{ft}$. In this study, the products produced from bathymetric-survey data were an area/capacity table and a bathymetric-contour map. The table and map quality can vary widely depending on the accuracy of the data used, the data-collection density, and the degree of data manipulation after collection.

Accuracy requirements and the means by which they are tested differ based on the accuracy standard that is chosen. Vertical accuracy is the principal criterion in specifying the quality of digital-elevation data. The National Map Accuracy Standard (NMAS; Bureau of the Budget, 1947) historically has been the standard for describing accuracy of map products. The Federal Geographic Data Committee (1998) published an alternative standard for map accuracy called the National Standard for Spatial Data Accuracy (NSSDA). This standard is more robust mathematically and can easily handle the large, high-accuracy spatial data sets that routinely are now being collected. The NSSDA method computes the vertical (or horizontal) root mean square error (RMSE) of the data using a high-accuracy independent data set. Assuming the errors are distributed normally, vertical (or horizontal) accuracy at the 95 percent confidence level is computed from the RMSE. The reported accuracy on all of the spatial data and derivative products in this report use the NSSDA standard unless stated otherwise. A comparison of the NMAS and NSSDA standard for vertical accuracy is given in table 1. The NSSDA vertical accuracy (Federal Geographic Data Committee, 1998) is computed using the following equations:

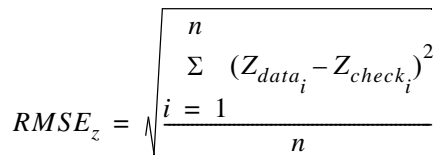

where

$R M S E_{z}$ is the Vertical Root Mean Square Error,

$$
\begin{aligned}
& Z_{\text {data }_{i}} \text { is the vertical coordinate of the } \mathrm{i}^{\text {th }} \text { check point in } \\
& \text { the data set, } \\
& Z_{\text {check }_{i}} \text { is the vertical coordinate of the } \mathrm{i}^{\text {th }} \text { check point in } \\
& \text { the quality assurance data set, } \\
& i \text { is an integer from } 1 \text { to } \mathrm{n} \text {; }
\end{aligned}
$$

and

$n$ is the number of points being checked.

$$
A_{z}=1.960 * R M S E_{z}
$$

where

$\mathrm{A}_{z}$ is the fundamental vertical accuracy calculated at the 95 percent confidence level.

The NSSDA horizontal accuracy (Federal Geographic Data Committee, 1998) is computed using the following equations:

$$
R M S E_{r}=\sqrt{\frac{\begin{array}{c}
n \\
\sum \\
i=1
\end{array}\left(X_{\text {data }_{i}}-X_{\text {check }_{i}}\right)^{2}-\left(Y_{\text {data }_{i}}-Y_{\text {check }_{i}}\right)^{2}}{n}}
$$

where

$R M S E_{r}$ is the Horizontal Root Mean Square Error,

$X_{\text {data }_{i}}$ is the horizontal $\mathrm{x}$-axis coordinate of the $\mathrm{i}^{\text {th }}$ check point in the data set,

$X_{\text {check }_{i}}$ is the horizontal x-axis coordinate of the $\mathrm{i}^{\text {th }}$ check point in the quality assurance data set,

$Y_{\text {data }_{i}}$ is the horizontal y-axis coordinate of the $\mathrm{i}^{\text {th }}$ check point in the data set,

$Y_{\text {check }_{i}}$ is the horizontal $\mathrm{y}$-axis coordinate of the $\mathrm{i}^{\text {th }}$ check point in the quality assurance data set.

$$
A_{r}=1.7308 * R M S E_{r}
$$

and

$A_{r} \quad$ is the horizontal accuracy calculated at the 95 percent confidence level.

A physical measurement has two parts; a numerical value supplying the best estimate of the quantity being measured, and the degree of uncertainty associated with the measurement. It is desirable to understand how different methods of bathymetric data collection and processing steps can affect the overall accuracy of the final products. Every step in the collection and processing of bathymetric-survey data has the potential to add uncertainty to the final products. By providing estimates of the errors associated with the data collection and processing steps, limits and guidelines can be established that will aid others when conducting bathymetric surveys. Understanding the sources of the uncertainties can help minimize the overall error when trying to meet the specified accuracy requirements.

The following discussions will focus mainly on the differences found in the accuracy of the products (surface model used to compute the area/capacity table and bathymetric-contour map) associated with differing data densities and processing steps. Included are the errors associated with the various steps used to collect and processes the bathymetric-survey data. This information can be used to estimate the accuracy of the final 
Table 1. Comparison of National Map Accuracy Standard (NMAS) and National Standard for Spatial Data Accuracy (NSSDA) Vertical Accuracy.

[ft, foot; VMAS, Vertical Map Accuracy Standard; RMSE ${ }_{\mathrm{z}}$, Vertical root mean square error; Accuracy $_{\mathrm{z}}$, vertical accuracy]

\begin{tabular}{|c|c|c|c|}
\hline \multicolumn{2}{|c|}{ National Map Accuracy Standard } & \multicolumn{2}{|c|}{ National Standard for Spatial Data Accuracy } \\
\hline $\begin{array}{l}\text { Equivalent } \\
\text { contour } \\
\text { interval } \\
\text { (ft) }\end{array}$ & $\begin{array}{c}\text { VMAS } \\
90 \text { percent confidence } \\
\text { level maximum error } \\
\text { tolerance } \\
\text { (ft) }\end{array}$ & $\begin{array}{c}\operatorname{RMSE}_{\mathrm{z}} \\
(\mathrm{ft})\end{array}$ & $\begin{array}{c}\text { Accuracy }_{\mathrm{z}^{\prime}} \\
95 \text { percent } \\
\text { confidence level } \\
\text { (ft) }\end{array}$ \\
\hline 1 & 0.5 & 0.30 & 0.60 \\
\hline 2 & 1 & .61 & 1.19 \\
\hline 3 & 1.5 & .92 & 1.80 \\
\hline 4 & 2 & 1.22 & 2.38 \\
\hline 5 & 2.5 & 1.52 & 2.98 \\
\hline 10 & 5 & 3.04 & 5.96 \\
\hline 20 & 10 & 6.08 & 11.92 \\
\hline 40 & 20 & 12.16 & 23.83 \\
\hline 80 & 40 & 24.32 & 47.66 \\
\hline
\end{tabular}

products so that future surveys can be designed to meet specific accuracy requirements and will provide a means of testing the accuracy of the final products so that a fundamental statement of accuracy can be made.

\section{Survey Data Accuracy}

Numerous factors affect the accuracy of the surveyed data. Positional (both horizontal and vertical) data accuracy during bathymetric surveys is affected by the type and quality of the depth measurement system, the resolution of measured depths, system calibration and alignment, vertical and horizontal reference datum accuracy, vessel draft/index errors, platform stability, vessel velocity, and subsurface material density.

To evaluate the vertical accuracy of the echo-sounder data collected during the survey of Sugar Creek Lake, multiple data sets were collected. The data sets included high-density (transects spaced at an approximately 50-ft interval) echosounder data, low-density (transects spaced at an approximately 490-ft interval) quality-assurance echo-sounder data, and manually-measured depths (fig. 6). A data set also was collected to evaluate the horizontal accuracy of the differential DGPS equipment used to determine the position of the echo sounder during the survey.

\section{Horizontal and Vertical Control Accuracy}

Under static surveying conditions, RTK GPS equipment is capable of producing centimeter-level accuracy (Trimble, 2001). Horizontal and vertical position accuracy for the data collected with the RTK GPS equipment was verified by recording differentially-corrected GPS positions with the receiving antenna set up over a known geodetic control point. The horizontal and vertical reference used in this study was a National Geodetic Survey benchmark (KD0053) located approximately 2 mi east of the lake (fig. 1). The geodetic control point used has a stated three- dimensional accuracy of $0.16 \mathrm{ft}$ as defined by its geodetic control network order (Moffit and Bossler, 1998). Because the horizontal and vertical accuracy of the benchmark and the survey-grade differentially-corrected GPS is far more accurate than the equipment used to collect position and depth data on the lake, it is assumed that the contribution to the overall error calculation of the survey is negligible.

\section{Echo-Sounder Data Vertical Accuracy}

According to the manufacturer's specifications, the survey-grade echo sounder used in this study has a resolution of better than $0.033 \mathrm{ft}$ for depths less than $328 \mathrm{ft}$ and an accuracy of +/- 0.5 percent (Ocean Data Equipment Corporation, 1997). Because the effects of vessel draft/index errors, platform stabil- 


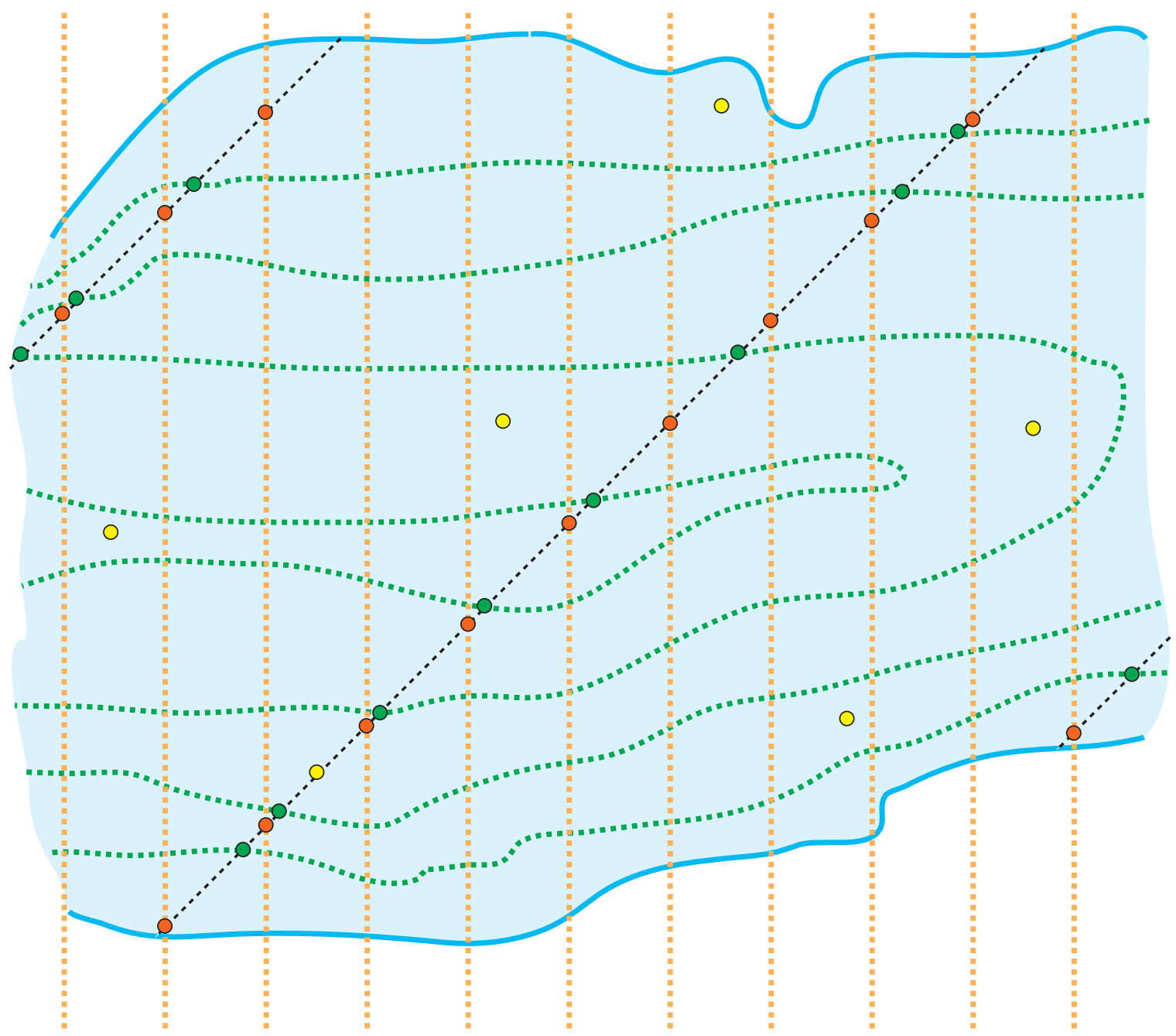

EXPLANATION

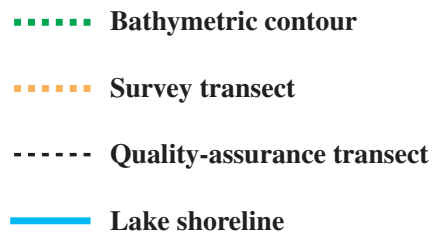

Comparison point

Survey transect depth and quality-assurance transect depth

Echo-sounder depth and manually measured depth

Bathymetric map depth and quality-assurance transect depth

Figure 6. Representation of survey data and bathymetric contours showing comparison points used to determine accuracy.

ity, vessel velocity, and subsurface material density on survey data accuracy are difficult to measure independently in the field, they were combined into a category called 'survey errors' and were assumed to be consistent throughout the survey. To determine the magnitude of the 'survey errors' during the survey of Sugar Creek Lake, echo-sounder depths at the intersections of the transect data and the quality-assurance transect data were compared (fig. 2). Points from the two data sets were considered coincident if the horizontal difference was less than $0.33 \mathrm{ft}$. At the intersections of the transects, 105 paired data points were found for comparison. The differences in the elevations of the two data sets were derived, and a vertical root mean square error $\left(\mathrm{RMSE}_{\mathrm{z}}\right)$ of $0.34 \mathrm{ft}$ (equation 1) was computed. Vertical accuracy of the 'survey errors' at the 95 percent confidence level was computed (equation 2) as $0.67 \mathrm{ft}$.

To determine the echo-sounder accuracy, echo-sounder depths were compared to manual depth measurements made using a weighted steel tape. Initially, it was assumed that the manual depth measurements would be more accurate than the echo-sounder depth measurements and that a comparison between the two would determine the accuracy of the echosounder depths. Thirty-one paired data points, with depths rang- 
ing from 4 to $26 \mathrm{ft}$, were compared and were found to have differences ranging from -0.1 to $+0.8 \mathrm{ft}$. Accuracy of the manually measured depths were likely affected by factors such as boat drift and an inability to determine sediment/water interface with the weighted steel tape. Evidence that the manually measured depths were in error was that mud was often stuck to the sides of the weight after the measurement, which indicated that the weight had sunk down into the soft sediment, and thus, the measurement did not represent the true sediment/water interface. Also, the average depth difference of $+0.3 \mathrm{ft}$ (manually-measured depth minus the echo-sounder depth) was an indication that the manual method over measured the depth. Assessing echo-sounder accuracy from these data sets was inconclusive because the manually measured depths were less accurate than the echo-sounder depths. This does, however, indicate that surveys conducted under similar conditions (lake bottom consisting of soft sediments), with just manually measured depths, would be less accurate than an echo-sounder survey.

Because the echo sounder collects depth data, vertical reference datum accuracy affects the data set when converting the depth data to elevation data. The vertical accuracy of the differentially-corrected GPS that is used to establish vertical control is a factor in the absolute vertical accuracy of the survey. As discussed in the previous section, because the reference datum and the GPS survey errors are small, they have been ignored in the vertical accuracy assessment of the bathymetric survey.

\section{Echo-Sounder Data Horizontal Accuracy}

Horizontal positional accuracy of echo-sounder survey data is affected by the horizontal reference datum accuracy, GPS satellite constellation geometry, vessel draft/index errors, platform stability, and vessel velocity. Manufacturer's specifications state the accuracy of the DGPS receiver is better than $3.28 \mathrm{ft}$ (Trimble, 1999). Although not tested independently during the survey process because echo-sounder points are not clearly defined points on the ground, the USGS performed calibration checks (described in the next paragraph) to ensure that the horizontal accuracy $\left(\mathrm{A}_{\mathrm{r}}\right)$ was equal to or better than $5.68 \mathrm{ft}$ (equation 4) at the 95 percent confidence level, equivalent to a radial RMSE (RMSE r $_{\mathrm{r}}$ ) of $3.28 \mathrm{ft}$.

To assess the horizontal accuracy of the DGPS, a set of test coordinates were collected and compared to coordinates collected with a survey-grade differentially-corrected GPS under controlled conditions in a parking lot. The test data set included 72 pairs of test coordinates. The differences in the coordinates of the two data sets were determined, and a radial root mean square error $\left(\mathrm{RMSE}_{\mathrm{r}}\right)$ of $0.10 \mathrm{ft}$ (equation 3) was computed. Horizontal accuracy $\left(\mathrm{A}_{\mathrm{r}}\right)$ at the 95 percent confidence level was computed (equation 4 ) to be $0.18 \mathrm{ft}$. To determine the affect that the changing GPS satellite constellation geometry had on the accuracy of a known coordinate for a given time period, 7,399 coordinates were collected over one known location for 6 hours and 19 minutes. The differences between the collected coordinates and the known coordinate were derived and a radial
$\mathrm{RMSE}_{\mathrm{r}}$ of $0.91 \mathrm{ft}$ (equation 3) was computed. Horizontal accuracy $\left(\mathrm{A}_{\mathrm{r}}\right)$ at the 95 percent confidence level was computed (equation 4) to be $1.57 \mathrm{ft}$. In both test cases, the DGPS tested well below the horizontal accuracy threshold value of $5.68 \mathrm{ft}$ at the 95 percent confidence level based on manufacture specifications and NSSDA standards.

\section{Target-Point Data Accuracy}

Because some target-point data were collected using the echo sounder at depths greater than about $2.6 \mathrm{ft}$, the vertical and horizontal accuracy of these data are assumed to be similar to the vertical and horizontal accuracy of echo-sounder data collected along the planned transects. For depths less than $2.6 \mathrm{ft}$, target-point data were collected manually using a wading rod. The vertical accuracy of measuring depth using a wading rod was not evaluated during this study, but it is assumed that the accuracy is greater than the echo-sounder vertical accuracy of $0.67 \mathrm{ft}$.

\section{Survey Product Accuracy}

Accuracy of the bathymetric-contour map and the area/ capacity table are affected by the survey data accuracy, the density of the survey data (transect interval and data-collection frequency), and the processing steps that occur during the creation of these products. The affect of transect intervals, data density along the transects, and the processing steps on the accuracy of the area/capacity table, bathymetric surface, and bathymetric map, were evaluated using comparison of different combinations of transect intervals, data density, and processing steps.

\section{Effect of Data Density on Area/Capacity Table Accuracy}

As mentioned in the methods section, the long axis of the lake was measured and divided into approximately 200 equal width increments, of approximately $50 \mathrm{ft}$ each, so that each interval represents approximately 0.5 percent of the total length (fig. 7). The 50-ft transect data set is considered the control data set for comparing the various transect intervals. The control data set was sub-sampled at 100-, 200-, 400-, and 800-ft intervals, which represent approximately $1,2,4$, and 8 percent of the total length of the lake, to create four additional data sets for analysis (figs. 8 to 11). Five area/capacity tables were generated from surface models created using transect intervals of 50, 100, 200, 400, and $800 \mathrm{ft}$ (table 2). Data density along the survey transects, which was approximately $1 \mathrm{ft}$, were not changed. The area/capacity tables generated from the 100-200-400- and 800$\mathrm{ft}$ transect intervals were compared to the area/capacity table generated from the control data set. Plots of the elevation-area curves and plots of the elevation-capacity curves for the 5 transect intervals are shown in figure 12. A plot of the relative percent difference for the elevation-area curves and for the ele- 
Table 2. Area/capacity tables from bathymetric surface created using different transect intervals.

[ft, foot]

\begin{tabular}{|c|c|c|c|c|c|c|c|c|c|c|}
\hline \multirow[b]{2}{*}{$\begin{array}{c}\text { Elevation } \\
\text { (ft) }\end{array}$} & \multicolumn{2}{|c|}{ 50-ft transect interval } & \multicolumn{2}{|c|}{$100-\mathrm{ft}$ transect interval } & \multicolumn{2}{|c|}{$200-\mathrm{ft}$ transect interval } & \multicolumn{2}{|c|}{$400-\mathrm{ft}$ transect interval } & \multicolumn{2}{|c|}{ 800-ft transect interval } \\
\hline & $\begin{array}{l}\text { Surface area } \\
\text { (acres) }\end{array}$ & $\begin{array}{l}\text { Volume } \\
\text { (acre-ft) }\end{array}$ & $\begin{array}{l}\text { Surface area } \\
\text { (acres) }\end{array}$ & $\begin{array}{l}\text { Volume } \\
\text { (acre-ft) }\end{array}$ & $\begin{array}{c}\text { Surface area } \\
\text { (acres) }\end{array}$ & $\begin{array}{l}\text { Volume } \\
\text { (acre-ft) }\end{array}$ & $\begin{array}{c}\text { Surface area } \\
\text { (acres) }\end{array}$ & $\begin{array}{l}\text { Volume } \\
\text { (acre-ft) }\end{array}$ & $\begin{array}{c}\text { Surface area } \\
\text { (acres) }\end{array}$ & $\begin{array}{l}\text { Volume } \\
\text { (acre-ft) }\end{array}$ \\
\hline 716 & 0.1 & 0.0 & 0 & 0 & 0 & 0 & 0 & 0 & 0.0 & 0.0 \\
\hline 718 & 11.9 & 8.1 & 11.6 & 7.7 & 10.8 & 6.2 & 7.3 & 4 & 2.3 & 0.7 \\
\hline 720 & 39.1 & 55.4 & 38.7 & 54.5 & 37.7 & 51.8 & 33.1 & 41.4 & 18.2 & 20.4 \\
\hline 722 & 68.7 & 163 & 68.1 & 161 & 66 & 155 & 58.9 & 134 & 37.3 & 76 \\
\hline 724 & 93.8 & 328 & 93.5 & 325 & 91.5 & 315 & 80.8 & 274 & 49.7 & 162 \\
\hline 726 & 117 & 539 & 117 & 535 & 113 & 520 & 98 & 453 & 62 & 273 \\
\hline 728 & 141 & 797 & 140 & 791 & 135 & 767 & 117 & 668 & 75 & 410 \\
\hline 730 & 164 & 1,100 & 163 & 1,090 & 157 & 1,060 & 136 & 920 & 90 & 570 \\
\hline 732 & 188 & 1,460 & 187 & 1,450 & 179 & 1,400 & 153 & 1,210 & 105 & 770 \\
\hline 734 & 214 & 1,860 & 211 & 1,850 & 201 & 1,780 & 169 & 1,530 & 121 & 1,000 \\
\hline 736 & 230 & 2,300 & 228 & 2,280 & 215 & 2,190 & 185 & 1,890 & 137 & 1,250 \\
\hline 738 & 245 & 2,780 & 242 & 2,750 & 230 & 2,640 & 203 & 2,280 & 155 & 1,550 \\
\hline 740 & 259 & 3,280 & 255 & 3,250 & 243 & 3,110 & 219 & 2,700 & 174 & 1,880 \\
\hline 742 & 279 & 3,820 & 275 & 3,780 & 263 & 3,620 & 238 & 3,150 & 195 & 2,240 \\
\hline 744 & 297 & 4,400 & 294 & 4,350 & 283 & 4,160 & 262 & 3,650 & 220 & 2,660 \\
\hline 746 & 314 & 5,010 & 312 & 4,960 & 305 & 4,750 & 289 & 4,200 & 251 & 3,130 \\
\hline 746.8 & 320 & 5,250 & 318 & 5,190 & 313 & 4,980 & 300 & 4,430 & 263 & 3,320 \\
\hline
\end{tabular}



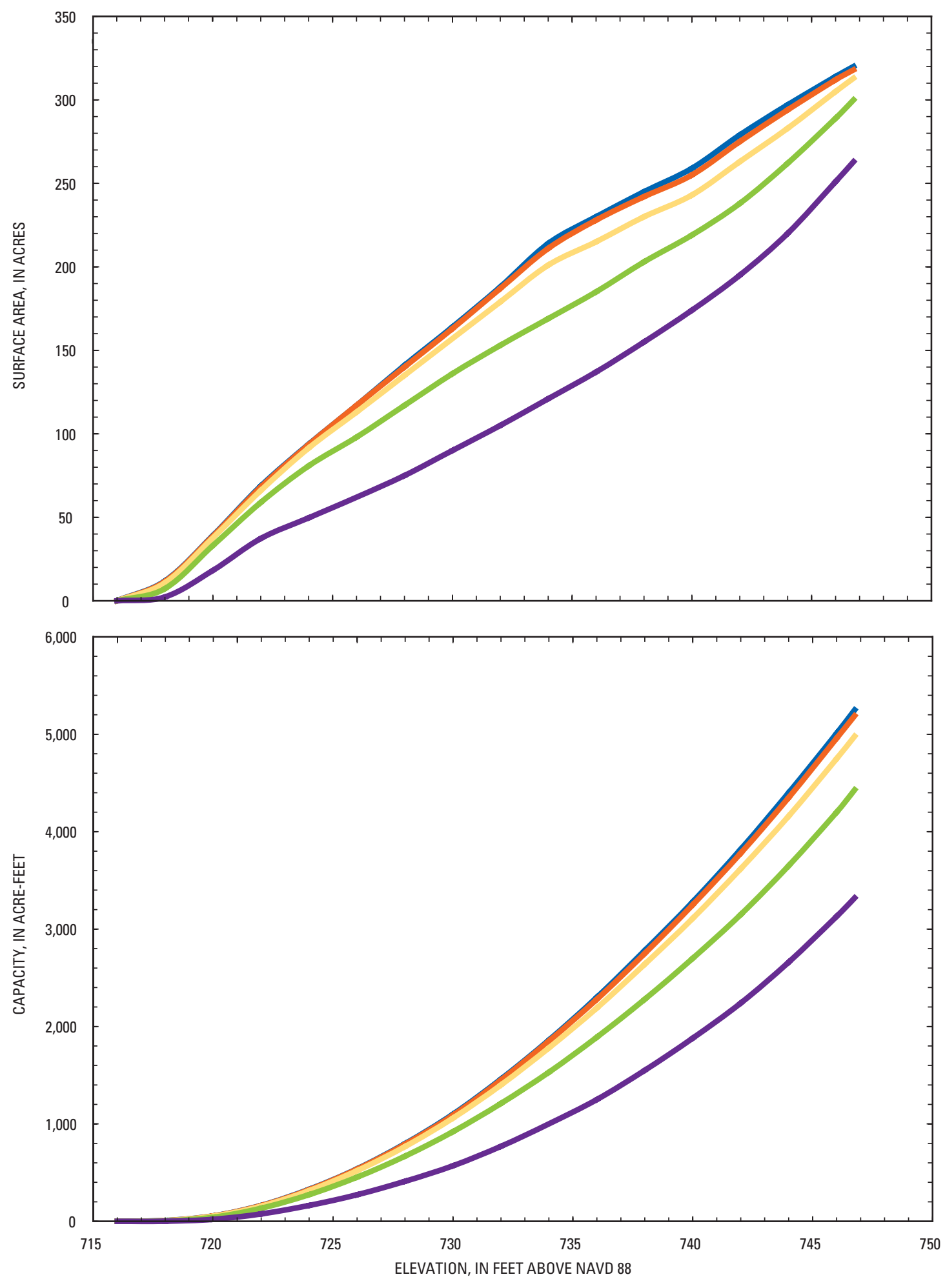

EXPLANATION

Transect interval, in feet

$$
\begin{array}{r}
50 \quad 400 \\
-100 \quad 800
\end{array}
$$

Figure 12. Elevation-area and elevation-capacity curves for bathymetric surfaces using different transect intervals. 
vation-capacity curves comparing the 50 -ft transect interval to the 100- 200-400- and 800-ft transect intervals is shown in figure 13. It should be noted that large percentage differences can occur even though the magnitude of the difference is small when the area and volume is small. At the Sugar Creek Lake full pool elevation of $746.8 \mathrm{ft}$, the area and volume differences in the area/capacity tables were 0.6 and 1.1 percent for the $100-\mathrm{ft}, 2.2$ and 5.1 percent for the 200-ft, 6.3 and 15.6 percent for the 400 $\mathrm{ft}$, and 17.8 and 36.8 percent for the $800-\mathrm{ft}$ transect intervals when compared to the 50-ft transect interval (fig. 13).

\section{Effect of Linear Enforcement on Area/Capacity Table Accuracy}

In an effort to improve the bathymetric surface model, linearity of topographic features such as valleys, bluffs, and ridges were enforced artificially in the data set. Linear-enforcement data were added along the length of these features so that they would be more realistically represented as continuous linear features in the surface models, based on professional judgment. Linear-enforcement data were added to the 100-, 200-, 400-, and $800-\mathrm{ft}$ transect data, and the area/capacity tables were recomputed (table 3 ) from the resulting bathymetric surface models. Plots of the elevation-area curves and the elevationcapacity curves for the 50-ft transect interval and the four transect intervals with linear-enforcement data added are shown in figure 14. A plot of the relative percent difference for the elevation-area curves and for the elevation-capacity curves comparing the 50-ft transect to the 100-, 200-, 400-, and 800-ft transect intervals with linear-enforcement data added is shown in figure 15. At the Sugar Creek Lake full pool elevation of $746.8 \mathrm{ft}$, the area and volume differences in the area/capacity tables were 0.3 and 1.0 percent, respectively, for the $100-\mathrm{ft}, 1.6$ and 3.4 percent for the $200-\mathrm{ft}, 2.8$ and 6.9 percent for the 400 $\mathrm{ft}$, and 6.3 and 12.2 percent for the $800-\mathrm{ft}$ transect intervals with linear-enforcement data added, when compared to the $50-\mathrm{ft}$ transect interval. It is evident from the plots (figs. 12 and 14) that the elevation-area and elevation-capacity curves for the 100-, 200-, 400-, and 800-ft transects with linear-enforcement data added to the surface models, plot closer to the control data set, than the curves generated from surface models without linear enforcement. This demonstrates that, although linearenforcement data improve the accuracy of the area/capacity tables and that the surface models with linear-enforcement data better represent the true bathymetric surface, transect intervals can be close enough that there is not a substantial difference in the area/capacity tables computed with or without linearenforcement data. Based on the data collected at Sugar Creek Lake, a transect interval equaling approximately 1 percent (or less) of the total longitudinal length of the lake would be sufficient to accurately determine the area/capacity table without any linear-enforcement data added. A transect interval between 1 percent and 4 percent of the total longitudinal length of the lake would require addition of linear-enforcement data to accurately determine the area/capacity. A transect interval of greater than 4 percent of the total longitudinal length of the lake is not dense enough to accurately compute the area/capacity table, even with linear-enforcement data added.

For Sugar Creek Lake, the surface model generated from the 100-ft transect interval, with or without linear-enforcement data, represented the bathymetric surface nearly as well as the surface model generated from the $50-\mathrm{ft}$ transect interval (when comparing area/capacity tables). The surface model generated from 200 - $\mathrm{ft}$ transect interval with linear-enforcement data represented the bathymetric surface reasonably well. Transect intervals of 400 and $800 \mathrm{ft}$, even with linear-enforcement data added to the surface model, were too large to adequately represent the bathymetric surface and calculate accurate area/capacity tables.

\section{Bathymetric Surface Accuracy}

The effect of linear enforcement on the vertical accuracy of the surface models was evaluated using the independently collected quality-assurance transect data set (21,647 points; fig. 2). Data density along the survey transects, which is approximately $1 \mathrm{ft}$, was not changed. The vertical accuracy of the surface model generated from the control data set (50-ft transect interval data) was $0.91 \mathrm{ft}$ at the 95 percent confidence interval (equation 2). This data set used only the echo-sounder, targetpoint, land-surface elevation, and supplemental topographic data with no linear-enforcement data added. For Sugar Creek Lake, adding linear-enforcement data to the echo-sounder data substantially increased the vertical accuracy of the surface model for transect intervals greater than $100 \mathrm{ft}$ (table 4). Linearenforcement data did not substantially improve the vertical accuracy of the 100-ft transect surface model.

The effect of data density along the survey transects on the vertical accuracy of the surface model was evaluated using 100$\mathrm{ft}$ transect data that were filtered to exclude data closer than 3.3, $6.6,13.1,26.2,52.5$, and $105 \mathrm{ft}$, and also were evaluated against the independently collected quality-assurance transect data set. Data collected along the 100-ft survey transects has an unfiltered density of approximately $1 \mathrm{ft}$. This unfiltered data set was used as the control data set for the comparison. An initial filtering distance of $3.3 \mathrm{ft}$ was chosen because of the stated horizontal accuracy of the DGPS receiver. The vertical accuracy was computed for the surface models generated from filtered transect data, with and without data that did and did not have linear-enforcement data added, to compare the affect linearenforcement data would have on the vertical accuracy as well (table 5). Data filtering does not appear to substantially affect the vertical accuracy of the surface models until the distance between data points is greater than about 25 percent of the transect interval. Surface models generated from data filtered at a distance greater than 50 percent of the transect interval do not represent the bathymetric surface as accurately. The addition of linear-enforcement data to transect data does not change the filtering distance at which the vertical accuracy of the surface model decreases substantially. The equipment used during this 

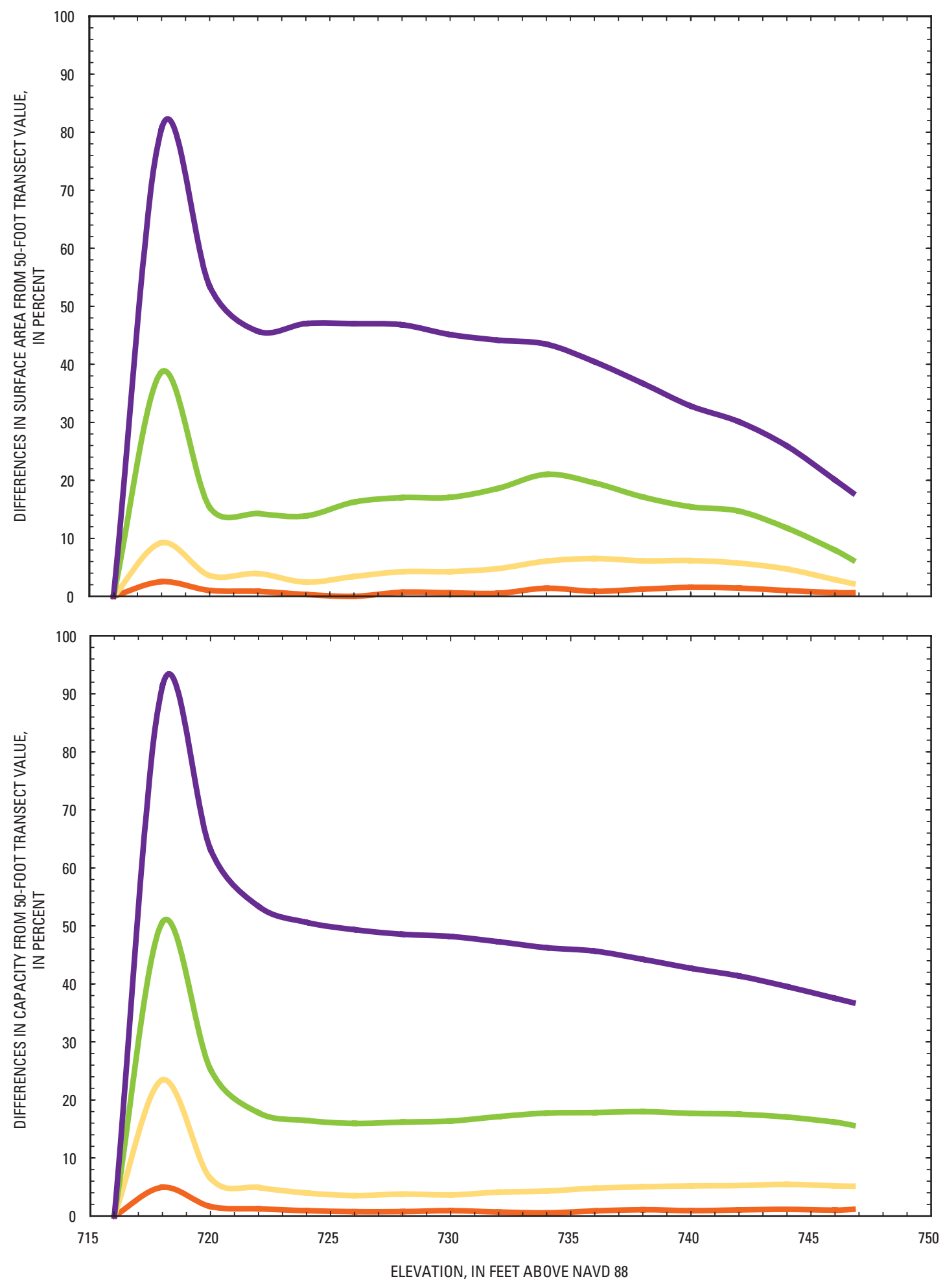

EXPLANATION

Transect interval, in feet

$$
\begin{array}{r}
100 \quad 400 \\
-200 \quad 800
\end{array}
$$

Figure 13. Relative percent difference of elevation-area and elevation-capacity curves from bathymetric surfaces created using different transect intervals as compared to the bathymetric surface created from 50 -foot transect intervals. 
Table 3. Area/capacity tables from bathymetric surface created using different transect intervals and linear-enforcement data.

\begin{tabular}{|c|c|c|c|c|c|c|c|c|c|c|}
\hline \multirow[b]{2}{*}{$\begin{array}{c}\text { Elevation } \\
\text { (ft) }\end{array}$} & \multicolumn{2}{|c|}{$50-\mathrm{ft}_{\text {transect interval }}{ }^{1}$} & \multicolumn{2}{|c|}{$100-\mathrm{ft}$ transect interval } & \multicolumn{2}{|c|}{$200-f t$ transect interval } & \multicolumn{2}{|c|}{ 400-ft transect interval } & \multicolumn{2}{|c|}{$800-f t$ transect interval } \\
\hline & $\begin{array}{c}\text { Surface area } \\
\text { (acres) }\end{array}$ & $\begin{array}{c}\text { Volume } \\
\text { (acre-ft) }\end{array}$ & $\begin{array}{c}\text { Surface area } \\
\text { (acres) }\end{array}$ & $\begin{array}{l}\text { Volume } \\
\text { (acre-ft) }\end{array}$ & $\begin{array}{c}\text { Surface area } \\
\text { (acres) }\end{array}$ & $\begin{array}{l}\text { Volume } \\
\text { (acre-ft) }\end{array}$ & $\begin{array}{c}\text { Surface area } \\
\text { (acres) }\end{array}$ & $\begin{array}{l}\text { Volume } \\
\text { (acre-ft) }\end{array}$ & $\begin{array}{c}\text { Surface area } \\
\text { (acres) }\end{array}$ & $\begin{array}{r}\text { Volume } \\
\text { (acre-ft) }\end{array}$ \\
\hline 716 & 0.1 & 0.0 & 0 & 0 & 0 & 0 & 0 & 0 & 0.0 & 0.0 \\
\hline 718 & 11.9 & 8.1 & 11.6 & 7.7 & 10.6 & 6.1 & 5.9 & 2.7 & 3.9 & 1.5 \\
\hline 720 & 39.1 & 55.4 & 38.9 & 54.7 & 38.1 & 51.2 & 33.1 & 39.6 & 21.8 & 24.7 \\
\hline 722 & 68.7 & 163 & 68.3 & 162 & 66.9 & 156 & 61.7 & 135 & 50.5 & 100 \\
\hline 724 & 93.8 & 328 & 93.7 & 326 & 92.4 & 317 & 88 & 284 & 72.3 & 222 \\
\hline 726 & 117 & 539 & 117 & 536 & 114 & 523 & 107 & 479 & 95 & 388 \\
\hline 728 & 141 & 797 & 140 & 792 & 136 & 773 & 130 & 717 & 118 & 600 \\
\hline 730 & 164 & 1,100 & 163 & 1,100 & 159 & 1,070 & 154 & 1,000 & 145 & 860 \\
\hline 732 & 188 & 1,460 & 187 & 1,450 & 181 & 1,410 & 175 & 1,330 & 170 & 1,170 \\
\hline 734 & 214 & 1,860 & 212 & 1,850 & 206 & 1,800 & 197 & 1,700 & 191 & 1,540 \\
\hline 736 & 230 & 2,300 & 228 & 2,290 & 220 & 2,220 & 213 & 2,110 & 204 & 1,930 \\
\hline 738 & 245 & 2,780 & 242 & 2,760 & 236 & 2,680 & 229 & 2,550 & 221 & 2,350 \\
\hline 740 & 259 & 3,280 & 255 & 3,250 & 250 & 3,160 & 243 & 3,020 & 236 & 2,810 \\
\hline 742 & 279 & 3,820 & 275 & 3,790 & 270 & 3,680 & 263 & 3,520 & 252 & 3,300 \\
\hline 744 & 297 & 4,400 & 294 & 4,360 & 289 & 4,240 & 284 & 4,070 & 273 & 3,820 \\
\hline 746 & 314 & 5,010 & 312 & 4,960 & 308 & 4,840 & 304 & 4,660 & 293 & 4,390 \\
\hline 746.8 & 320 & 5,250 & 319 & 5,200 & 315 & 5,070 & 311 & 4,890 & 300 & 4,610 \\
\hline
\end{tabular}

${ }^{1}$ No linear-enforcement data were used for bathymetric surface created from $50-\mathrm{ft}$ transects. 

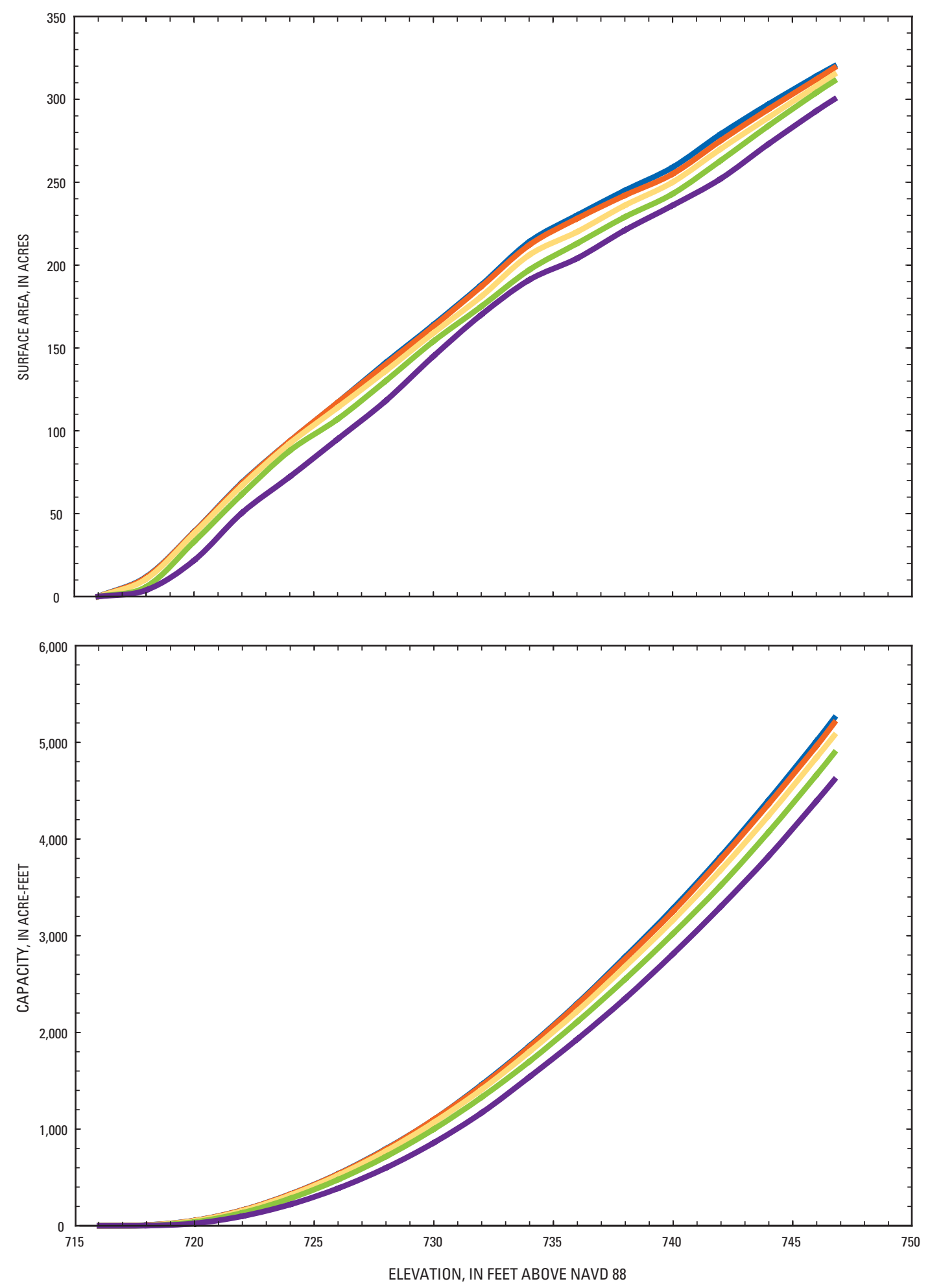

EXPLANATION

Transect interval, in feet

$$
\begin{array}{rr}
50 & 400 \\
100 & 800 \\
200 &
\end{array}
$$

Figure 14. Elevation-area and elevation-capacity curves for bathymetric surfaces using different transect intervals and linear-enforcement data. 

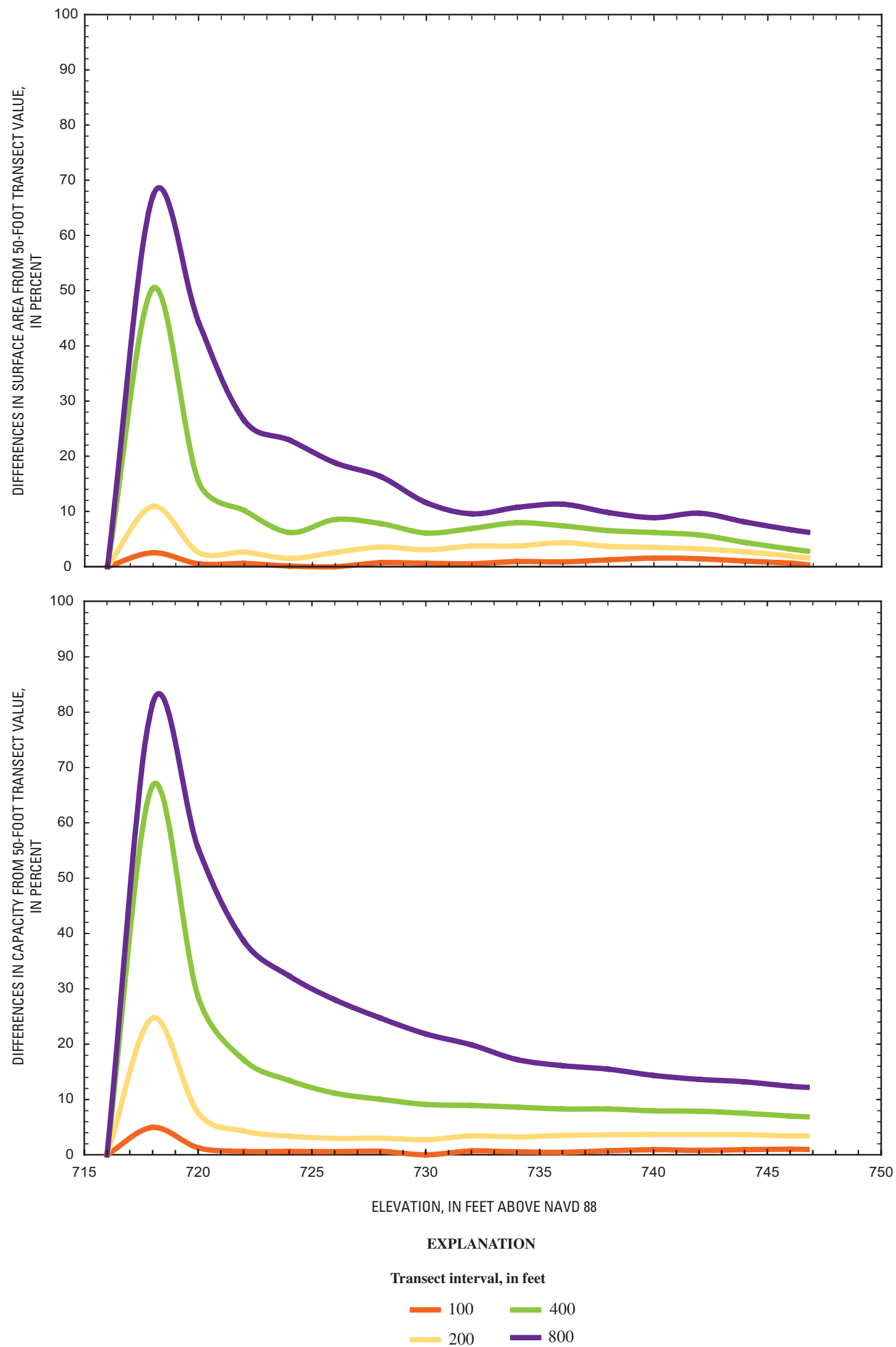

Figure 15. Relative percent difference of elevation-area and elevation-capacity curves from bathymetric surfaces created using different transect intervals and linear-enforcement data as compared to the bathymetric surface created from 50 -foot transect intervals. 
survey collected data of sufficient density along the transect, and it is not necessary to filter the data because of the current computer processing capabilities.

Table 4. Vertical accuracies (at the 95 percent confidence level) of bathymetric surfaces created using different transect intervals without and with linear-enforcement data.

[ft, foot; --, no linear-enforcement data was used]

\begin{tabular}{ccc}
\hline & \multicolumn{2}{c}{ Vertical accuracy (ft) } \\
\cline { 2 - 3 } $\begin{array}{c}\text { Transect } \\
\text { interval } \\
\text { (ft) }\end{array}$ & $\begin{array}{c}\text { Without linear- } \\
\text { enforcement } \\
\text { data }\end{array}$ & $\begin{array}{c}\text { With linear- } \\
\text { enforcement } \\
\text { data }\end{array}$ \\
\hline 50 & 0.91 & -- \\
100 & 1.54 & 1.46 \\
200 & 3.71 & 2.83 \\
400 & 7.30 & 3.95 \\
800 & 15.55 & 5.83 \\
\hline
\end{tabular}

\section{Bathymetric Map Accuracy}

Vertical accuracy of the cartographically-edited 2-ft contour maps produced from the 50-, 100-, 200-, 400-, and 800-ft transect data with linear-enforcement data added was assessed by comparing the elevations of the quality-assurance transect data with the elevation contours at coincident locations. Quality-assurance transect points were considered coincident with the contour if a transect point was located within $0.33 \mathrm{ft}$ of the contour. The number of coincident points between the 50-, 100-, 200-, 400-, and 800-ft transect data and quality-assurance transect data was $363,335,325$, and 337, respectively. Computed NSSDA fundamental vertical accuracy (equation 2) of the 50-, 100-, 200-, 400-, and 800-ft transects were 1.51, 2.76, $4.54,6.33$, and $7.30 \mathrm{ft}$, respectively; these vertical accuracy values were converted to equivalent NMAS contour intervals by interpolating from table 1 . The NMAS equivalent contour interval values for the 50-, 100-, 200-, 400-, and 800-ft transects were approximately $2.5,4.6,7.6,10.6$ and $12.2 \mathrm{ft}$, respectively.

The NSSDA vertical accuracy decreases as each data set is produced in the process of creating the final contour map. For example, techniques used to process the raw data points to generate the surface model decreases the NSSDA vertical accuracy, and the process of generating contours from the surface model further decreases vertical accuracy. For Sugar Creek Lake, the NSSDA vertical accuracy for the echo-sounder data was computed as $0.67 \mathrm{ft}$, the surface model created using the $50-\mathrm{ft}$ transect interval had a NSSDA vertical accuracy of $0.91 \mathrm{ft}$, and the bathymetric contours created from the surface model had a NSSDA vertical accuracy of $1.51 \mathrm{ft}$. To improve the vertical accuracy of the bathymetric contours, though impractical because of the inability to guide the boat on the proposed transect, closer transect intervals would be needed. Decreasing transect spacing, however, increases the difficulty of maintaining boat position along the planned survey transects. Also, the NSSDA vertical accuracy is limited by the vertical accuracy of the current echo-sounder equipment and resulting data $(0.67 \mathrm{ft})$. It is clear that even at the 50 -ft transect interval, the data are not sufficiently dense to create a NMAS 2-ft contour interval map (NSSDA vertical accuracy of $1.19 \mathrm{ft}$ ). However, contours of any interval may be provided on a map if the calculated NSSDA vertical accuracy of the contour is specified on the map. Horizontal accuracy of the bathymetric contour maps was not determined, but it is assumed that because of cartographic editing, the horizontal accuracy is decreased relative to the horizontal accuracy of the data points.

Table 5. Vertical accuracies (at the 95 percent confidence level) of bathymetric surfaces created using 100-foot transect interval data, without and with linear-enforcement data, and different filtering distances.

\begin{tabular}{ccc} 
[ft, foot] & \multicolumn{2}{c}{ Vertical accuracy (ft) } \\
\hline $\begin{array}{c}\text { Filtering } \\
\text { distance } \\
\text { (ft) }\end{array}$ & $\begin{array}{c}\text { Without linear- } \\
\text { enforcement } \\
\text { data }\end{array}$ & $\begin{array}{c}\text { With linear- } \\
\text { enforcement } \\
\text { data }\end{array}$ \\
\hline 0 & 1.54 & 1.46 \\
3.3 & 1.54 & 1.45 \\
6.6 & 1.55 & 1.44 \\
13.1 & 1.57 & 1.43 \\
26.2 & 1.71 & 1.52 \\
52.5 & 2.10 & 1.85 \\
105 & 4.66 & 4.02 \\
\hline
\end{tabular}

When comparing the contour maps created from the 100-, 200-, 400-, and 800-ft transect data (with linear-enforcement data added to the surface models) to the contour map created from the 50-ft transect data (figs. 16 to 20), features such as creek channels, small depressions/mounds, and overall contour sinuosity are defined in less detail with increasing transect interval. It was assumed that the overall length of a contour becomes shorter as detail is lost. In an attempt to quantify the loss of cartographic detail numerically, the length of the individual elevation contours from the 100-, 200-, 400-, and 800-ft transect data were compared to the length of the same contours generated from the 50 -ft transect data (table 6). Generally, as the transect interval increases, the length of the contours decrease. The 
Table 6. Contour lengths from bathymetric surface models created using different transect intervals and linear-enforcement data with percent differences from the control data set (50-foot transect interval).

\begin{tabular}{|c|c|c|c|c|c|c|c|c|c|}
\hline \multirow[b]{2}{*}{$\begin{array}{c}\text { Elevation } \\
\text { (ft) }\end{array}$} & \multirow{2}{*}{$\begin{array}{c}\text { 50-ft transect interval } \\
\text { (control data set) }\end{array}$} & \multicolumn{2}{|c|}{$\begin{array}{c}100-\mathrm{ft} \text { transect interval } \\
\text { (with linear-enforcement data) }\end{array}$} & \multicolumn{2}{|c|}{$\begin{array}{c}\text { 200-ft transect interval } \\
\text { (with linear-enforcement data) }\end{array}$} & \multicolumn{2}{|c|}{$\begin{array}{c}\text { 400-ft transect interval } \\
\text { (with linear-enforcement data) }\end{array}$} & \multicolumn{2}{|c|}{$\begin{array}{c}\text { 800-ft transect interval } \\
\text { (with linear-enforcement data) }\end{array}$} \\
\hline & & $\begin{array}{l}\text { Contour } \\
\text { length } \\
\text { (ft) }\end{array}$ & $\begin{array}{c}\text { Percent } \\
\text { difference from } \\
\text { control data set }\end{array}$ & $\begin{array}{l}\text { Contour } \\
\text { length } \\
\text { (ft) }\end{array}$ & $\begin{array}{l}\text { Percent } \\
\text { difference from } \\
\text { control data set }\end{array}$ & $\begin{array}{l}\text { Contour } \\
\text { length } \\
\text { (ft) }\end{array}$ & $\begin{array}{c}\text { Percent } \\
\text { difference from } \\
\text { control data set }\end{array}$ & $\begin{array}{l}\text { Contour } \\
\text { length } \\
\text { (ft) }\end{array}$ & $\begin{array}{c}\text { Percent } \\
\text { difference from } \\
\text { control data set }\end{array}$ \\
\hline 716 & 746 & 277 & 62.9 & 0 & 100.0 & 0 & 100.0 & 0 & 100.0 \\
\hline 718 & 6,480 & 6,390 & 1.4 & 5,340 & 17.6 & 3,720 & 42.6 & 2,540 & 60.8 \\
\hline 720 & 8,240 & 8,130 & 1.3 & 7,840 & 4.9 & 7,250 & 12.0 & 6,050 & 26.6 \\
\hline 722 & 10,700 & 10,600 & .9 & 10,500 & 1.9 & 8,810 & 17.7 & 7,640 & 28.6 \\
\hline 724 & 12,500 & 12,500 & .0 & 12,400 & .8 & 11,700 & 6.4 & 10,600 & 15.2 \\
\hline 726 & 15,100 & 14,900 & 1.3 & 14,900 & 1.3 & 14,600 & 3.3 & 12,800 & 15.2 \\
\hline 728 & 18,100 & 18,000 & .6 & 18,100 & .0 & 17,600 & 2.8 & 16,600 & 8.3 \\
\hline 730 & 21,600 & 21,500 & .5 & 21,800 & -.9 & 21,200 & 1.9 & 19,500 & 9.7 \\
\hline 732 & 28,300 & 27,900 & 1.4 & 26,500 & 6.4 & 25,100 & 11.3 & 23,700 & 16.3 \\
\hline 734 & 31,600 & 31,400 & .6 & 31,900 & -.9 & 30,500 & 3.5 & 28,100 & 11.1 \\
\hline 736 & 34,900 & 34,800 & .3 & 35,000 & -.3 & 33,700 & 3.4 & 30,100 & 13.8 \\
\hline 738 & 37,900 & 37,900 & .0 & 37,800 & .3 & 36,100 & 4.7 & 32,900 & 13.2 \\
\hline 740 & 41,800 & 41,800 & .0 & 40,800 & 2.4 & 38,500 & 7.9 & 35,800 & 14.4 \\
\hline 742 & 47,000 & 46,600 & .9 & 45,800 & 2.6 & 43,300 & 7.9 & 39,200 & 16.6 \\
\hline 744 & 52,000 & 51,300 & 1.3 & 49,300 & 5.2 & 47,200 & 9.2 & 42,400 & 18.5 \\
\hline 746 & 55,900 & 55,200 & 1.3 & 52,800 & 5.5 & 51,600 & 7.7 & 46,800 & 16.3 \\
\hline
\end{tabular}


greatest percent differences are at the lower elevations of the lake bottom because these contour lengths are shorter and the absolute differences are large relative to the contour length.

When comparing the contours from the 50-ft transect interval control data set, (fig. 16) to the contours generated from the 100-ft transect interval (fig. 17), they appear very similar. Specifically, the 718-ft contour near the dam defining a creek channel in the lake bottom appears only slightly different. When comparing the contours from the control data set to the contours generated from the 200-ft transect interval (fig. 18), some substantial differences can be seen. The 718 -ft contour defining a creek channel in the lake bottom is not continuous. When comparing the contours from the control data set to the contours generated from the 400- and 800-ft transect interval (figs. 19 and 20), features such as creeks, small depressions, and the bottoms of coves are not accurately detailed. The 718-ft contour no longer defines a creek channel.

For Sugar Creek Lake, the contours from 100-ft transect interval data (fig. 17) appeared to represent the detail of the bathymetric surface nearly as well as the contours from the 50$\mathrm{ft}$ transect interval (fig. 16) and the contours from the 200-ft transect interval (fig. 18) appear to represent the detail of the bathymetric surface reasonably well, but with some substantial loss of detail in the bottom of the lake. Contours from the 400and 800-ft transects (figs. 19 and 20) appear to have substantial loss of detail of the bathymetric surface relative to the contours from the 50-ft transects. This information demonstrates that for Sugar Creek Lake, and perhaps lakes of similar size and geometry, a transect interval representing approximately 1 percent (or less) of the total longitudinal length of the lake would produce an adequately detailed contour map. Actually, bathymetric map accuracy depends on absolute transect spacing and not relative spacing as indicated by the decrease in NSSDA vertical accuracies corresponding with the increase in transect spacing. As a result, the map accuracy guidelines apply only to lakes that have similar size and geometry of Sugar Creek Lake. For example, the bathymetric map accuracy of much larger lakes with a transect intervals of 400-800 feet would not be expected to be the same as smaller lakes with transect intervals of 50-100 feet even though both sets of transect intervals are approximately 1 percent of the longitudinal length of the lakes. Previous surveys conducted at other lakes, with surface areas ranging from 14 to 1,000 acres and capacities ranging from 140 to 15,900 acre-ft, have produced similar results (table 7). The transect interval of these surveys ranged from 30 to $130 \mathrm{ft}$.

Table 7. Bathymetric surface and contour accuracies of previously surveyed lakes with similar size and geometry processed using documented procedures.

[ft, foot]

\begin{tabular}{rrccc}
\hline $\begin{array}{c}\text { Area } \\
\text { (acres) }\end{array}$ & $\begin{array}{c}\text { Capacity } \\
\text { (acre-ft) }\end{array}$ & $\begin{array}{c}\text { Transect } \\
\text { interval } \\
\text { (ft) }\end{array}$ & $\begin{array}{c}\text { Surface } \\
\text { accuracy } \\
\text { (ft) }\end{array}$ & $\begin{array}{c}\text { Map accuracy } \\
\text { (ft) }\end{array}$ \\
\hline 14 & 140 & 30 & 1.55 & 1.91 \\
26 & 174 & 30 & .74 & .52 \\
28 & 460 & 30 & 1.72 & 2.44 \\
29 & 317 & 30 & 1.67 & 1.73 \\
40 & 354 & 30 & .94 & 1.41 \\
45 & 1,240 & 30 & 2.28 & 2.67 \\
75 & 640 & 65 & 1.5 & 2.47 \\
330 & 5,300 & 50 & .91 & 1.51 \\
493 & 8,700 & 100 & 1.95 & 3.01 \\
583 & 12,500 & 100 & 1.47 & 2.92 \\
1,000 & 15,900 & 130 & 1.62 & 2.78 \\
\hline
\end{tabular}




\section{Procedural Documentation and Accuracy Assessment of Bathymetric Maps and Area/Capacity Tables for Small Reservoirs}

\section{Summary}

A bathymetric survey was performed on Sugar Creek Lake near Moberly, Missouri, in December 2003. The survey was performed using a survey-grade echo sounder to collect water depths and a differentially-corrected global positioning system (DGPS) receiver mounted above the echo sounder to collect horizontal position. A survey-grade differentially-corrected GPS (hereafter referred to as RTK GPS) using real-time kinematic corrections was used to establish vertical and horizontal control and to collect land-surface elevation data above the water surface. The results of the survey included an area/capacity table, a bathymetric-contour map of the lake, and an assessment of the accuracy of the two products.

Initial survey planning required digitizing the lake boundary from an aerial photograph (preferred) or from a topographic map source. A set of planned transects were then created to organize the field data collection. The spacing of the planned transects is dependent on the intended product and the required accuracy. An independent data set was collected along a second set of transects oriented at an oblique angle (30 to 45 degrees) to the first survey transects, and were used to quantify the accuracy of the echo soundings, bathymetric surface, and bathymetric-contour map.

Water-depth and coordinate data were collected along the planned transects using a boat-mounted survey-grade echo sounder and DGPS. Additional water-depth and coordinate data were collected as needed to better define areas where the lake bottom elevation changes rapidly. In areas that were too shallow for the echo sounder, such as coves, water depths were measured manually. Coordinates defining the edge of the water surface of the lake also were collected. Horizontal and vertical control was established using a RTK GPS set up over a known geodetic control point. Two additional known geodetic control points were surveyed to ensure stability of all control points used. Land-surface elevations and coordinates were collected using a differentially-corrected GPS receiver.

The water-depth and coordinate data were post-processed and imported into a geographic information system (GIS) database along with information from maps, field notes, and photographs. A bathymetric surface model was created and contoured using the combined data sets. The generated contours were reviewed for proper linear interpretation of the data. Breakline data were added to areas to enforce the proper linear interpretation of the data. This is an iterative process that is dependent on the lake size, data density, and type of topographic features in the lake bottom. An area/capacity table was calculated from the final bathymetric surface model, and contours generated from the final bathymetric surface model were cartographically edited for map production.

An accuracy assessment was performed on the collected data, bathymetric surface model, and bathymetric contour map. The horizontal and vertical accuracy of the geodetic control used to establish the datum, and the survey-grade GPS used to transfer the datum to the lake and to collect elevation data above the lake water surface, were accepted as being much better than the accuracy of equipment used to collect water-depth and coordinate data from the survey boat and, therefore, were neglected in the overall accuracy assessment.

To evaluate the accuracy of the measured depths from the survey-grade echo sounder, data collected along the 50-ft transects were compared to the independent quality-assurance data set. The National Standard for Spatial Data Accuracy (NSSDA) vertical accuracy of the echo-sounder data, at the 95 percent confidence level, was computed as $0.67 \mathrm{ft}$ (foot). Because of the collection method, additional manually measured depth data, or target points, were assumed to be more accurate than the computed vertical echo-sounder accuracy. The NSSDA horizontal radial accuracy of the DGPS coordinates used with the echo-sounder depth data was computed to be $1.57 \mathrm{ft}$ at the 95 percent confidence level, which was within the manufacturer's specified accuracy of less than $3.28 \mathrm{ft}$.

To evaluate the affect of linear-enforcement data on the accuracy of the computed area/capacity tables, results obtained using the most dense transect interval (approximately 0.5 percent of total lake length), were compared to results obtained using larger transect intervals (approximately 1, 2, 4, and 8 percent total lake length). For Sugar Creek Lake, a transect interval of approximately 1 percent of the longitudinal length of the lake resulted in an area/capacity computation nearly as accurate as the more dense transect interval. It also was determined that the addition of linear-enforcement data improved the accuracy of the area/capacity tables. However, the accuracy of the area/ capacity tables were not substantially increased (using linearenforcement data) for transect intervals of less than 2 percent of the longitudinal length (100 ft). For future surveys, adding linear-enforcement data to bathymetric surfaces are unnecessary if generating area/capacity tables is the only objective, and transect spacing is sufficiently dense.

To evaluate the affect of transect density, data density along the transect on the accuracy of the computed bathymetric surface were determined by comparing the elevations of surface models, generated from different transect intervals, with the independent quality-assurance depth data. The NSSDA vertical accuracy of the bathymetric surfaces generated from the $0.5,1$, 2,4 , and 8 percent transect intervals (with linear-enforcement data) were $0.91,1.46,2.83,3.95$, and $5.83 \mathrm{ft}$, respectively at the 95 percent confidence interval. The addition of linear-enforcement data improved the vertical accuracies of the surface models created from transect intervals greater than 1 percent of the longitudinal length of the lake. Data density along the transect does not appear to substantially affect the vertical accuracy of the bathymetric surface until the spacing is greater than 25 percent of the transect interval. The equipment used during this survey collected data of sufficient density along the transect, and it is not necessary to filter the data because of the current computer processing capabilities.

Vertical accuracy of the bathymetric contour maps produced from transect intervals of $0.5,1,2,4$, and 8 percent of the longitudinal distance of the lake (with linear-enforcement data added to the bathymetric surface), was determined by compar- 
ing elevations of the quality-assurance transect data to the elevations of the contours at coincident locations. The NSSDA vertical accuracies were determined to be $1.51,2.76,4.54,6.33$, and $7.30 \mathrm{ft}$, respectively. The National Map Accuracy Standard (NMAS) equivalent contour intervals for the maps produced from transect intervals of $0.5,1,2,4$, and 8 percent (with linearenforcement data added) were 2.5, 4.6, 7.6, 10.6, and $12.2 \mathrm{ft}$, respectively. For these data sets, the best NMAS contour interval possible was $2.5 \mathrm{ft}$; however, contours of any interval may be provided on the map as long as the NSSDA vertical accuracy is specified. The amount of detail in the bathymetric contours was also found to be dependent on the transect interval. A numerical determination of the loss of detail in the contour maps was made by assuming that contours with less detail are shorter. It was determined that contours produced from a transect interval of 1 percent of the longitudinal length of the lake had minimal loss of detail compared to the contours produced from the transects spaced at 0.5 percent of the longitudinal length of the lake.

\section{References}

Bureau of the Budget, 1947, National Map Accuracy Standards: Office of Management and Budget, Washington, D.C.

Environmental Systems Research Institute, 1982-2005, ArcDoc Version 9.1, Redlands, CA.

Environmental Systems Research Institute, 2005, ArcGIS, accessed February 28, 2005, at http://www.esri.com/software/arcgis/.

Federal Geographic Data Committee, 1998, Geospatial Positioning Accuracy Standards, Part 3: National Standard for Spatial Data Accuracy, Federal Geographic Data Committee, U.S. Geological Survey, www.fgdc.gov/standards/documents/standards/accuracy/chapter3.pdf.

Fenneman, N.M., 1938, Physiography of the eastern United States: New York, McGraw Hill, 714 p.

Hauck, H.S., and Nagel, C.D., 2004, Water resources data, Missouri, water year 2004: U.S. Geological Survey WaterData Report MO-04-01, 791 p.

Moffit, F.H., and Bossler, J.D., 1998, Surveying, Tenth Edition: Addison Wesley Longman, Inc., 738 p.

National Oceanic and Atmospheric Administration (NOAA), 2003, Climatological Data Annual Summary for Missouri: Asheville, N.C., National Climate Center, v. 107, no. 13, $32 \mathrm{p}$.

Ocean Data Equipment Corporation, 1997, Bathy-500MF, Survey Echo Sounder, owner's manual: Walpole, MA, 39 p. with appendices.

Trimble Navigation Limited, 1999, AgGPS 124/132 Operation Manual, Revision B: Trimble Precision Agricultural Systems: Overland Park, KS, 218 p.

Trimble Navigation Limited, 2001, 5700 GPS Receiver User Guide: Trimble, Land Survey Division, Sunnyvale, CA, $168 \mathrm{p}$.
U.S. Army Corps of Engineers (USACE), 2002, Engineering and Design-Hydrographic Surveying Manual No. 1110-21003: Washington, D.C., 510 p. 


\section{Oversized Figures}

[Click on figure title to view]

2. Map showing planned 50-foot interval survey and 490-foot interval quality-assurance transects at Sugar Creek Lake near Moberly, Missouri

7-11. Maps showing-

7. Echo-sounder, target-point, and land-survey data collected at Sugar Creek Lake near Moberly, Missouri, with shoreline digitized from aerial photography, used to create the bathymetric surface model using a transect interval of approximately 50 feet

8. Echo-sounder, target-point, and land-survey data collected at Sugar Creek Lake near Moberly, Missouri, with shoreline digitized from aerial photography, used to create the bathymetric surface model using a transect interval of approximately 100 feet and linear-enforcement data

9. Echo-sounder, target-point, and land-survey data collected at Sugar Creek Lake near Moberly, Missouri, with shoreline digitized from aerial photography, used to create the bathymetric surface model using a transect interval of approximately 200 feet and linear-enforcement data

10. Echo-sounder, target-point, and land-survey data collected at Sugar Creek Lake near Moberly, Missouri, with shoreline digitized from aerial photography, used to create the bathymetric surface model using a transect interval of approximately 400 feet and linear-enforcement data

11. Echo-sounder, target-point, and land-survey data collected at Sugar Creek Lake near Moberly, Missouri, with shoreline digitized from aerial photography, used to create the bathymetric surface model using a transect interval of approximately 800 feet and linear-enforcement data

16-20. Maps showing-

16. Bathymetric contours of Sugar Creek Lake near Moberly, Missouri, created from a transect interval of approximately 50 feet

17. Bathymetric contours of Sugar Creek Lake near Moberly, Missouri, created from a transect interval of approximately 100 feet and linear-enforcement data

18. Bathymetric contours of Sugar Creek Lake near Moberly, Missouri, created from a transect interval of approximately 200 feet and linear-enforcement data

19. Bathymetric contours of Sugar Creek Lake near Moberly, Missouri, created from a transect interval of approximately 400 feet and linear-enforcement data

20. Bathymetric contour map of Sugar Creek Lake near Moberly, Missouri, created from a transect interval of approximately 800 feet and linear-enforcement data 


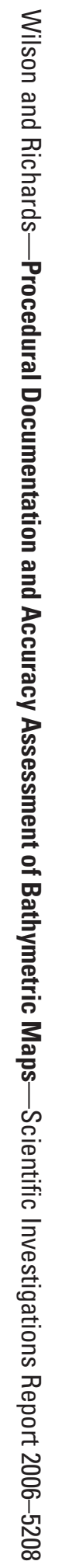

4 Printed on recycled paper 